\title{
Study on antibacterial alginate-stabilized copper nanoparticles by FT-IR and 2D-IR correlation spectroscopy
}

\author{
Judith Díaz-Visurraga ${ }^{1,2}$ \\ Carla Daza ${ }^{2}$ \\ Claudio Pozo 2 \\ Abraham Becerra ${ }^{2}$ \\ Carlos von Plessing 1,2 \\ Apolinaria García ${ }^{3}$ \\ 'Department of Pharmacy, Faculty \\ of Pharmacy, University of \\ Concepcion; ${ }^{2}$ Research Center \\ of Advanced Polymers (CIPA), \\ CONICYT REGIONAL/CIPA \\ R08C 1002; ${ }^{3}$ Department of \\ Microbiology, Faculty of Biological \\ Sciences, University of Concepcion, \\ Concepción, Chile
}

This article was published in the following Dove Press journal: International Journal of Nanomedicine 10 July 2012 Number of times this article has been viewed

Background: The objective of this study was to clarify the intermolecular interaction between antibacterial copper nanoparticles ( $\mathrm{Cu}$ NPs) and sodium alginate (NaAlg) by Fourier transform infrared spectroscopy (FT-IR) and to process the spectra applying two-dimensional infrared (2D-IR) correlation analysis. To our knowledge, the addition of NaAlg as a stabilizer of copper nanoparticles has not been previously reported. It is expected that the obtained results will provide valuable additional information on: (1) the influence of reducing agent ratio on the formation of copper nanoparticles in order to design functional nanomaterials with increased antibacterial activity, and (2) structural changes related to the incorporation of $\mathrm{Cu}$ NPs into the polymer matrix.

Methods: $\mathrm{Cu}$ NPs were prepared by microwave heating using ascorbic acid as reducing agent and NaAlg as stabilizing agent. The characterization of synthesized $\mathrm{Cu}$ NPs by ultraviolet visible spectroscopy, transmission electron microscopy (TEM), electron diffraction analysis, X-ray diffraction (XRD), and semiquantitative analysis of the weight percentage composition indicated that the average particle sizes of $\mathrm{Cu}$ NPs are about 3-10 nm, they are spherical in shape, and consist of zerovalent $\mathrm{Cu}$ and $\mathrm{Cu}_{2} \mathrm{O}$. Also, crystallite size and relative particle size of stabilized $\mathrm{Cu}$ NPs were calculated by XRD using Scherrer's formula and FT from the X-ray diffraction data. Thermogravimetric analysis, differential thermal analysis, differential scanning calorimetry (DSC), FT-IR, second-derivative spectra, and 2D-IR correlation analysis were applied to studying the stabilization mechanism of $\mathrm{Cu}$ NPs by NaAlg molecules. The minimum inhibitory concentration (MIC) and minimum bactericidal concentration (MBC) of stabilized $\mathrm{Cu}$ NPs against five bacterial strains (Staphylococccus aureus ATCC 6538P, Escherichia coli ATCC 25922 and O157: H7, and Salmonella enterica serovar Typhimurium ATCC 13311 and 14028) were evaluated with macrodilution, agar dilution plate count, and well-diffusion methods.

Results: On the basis of the semiquantitative analysis, there was a direct correlation between the reducing agent ratio and the percentage of zerovalent $\mathrm{Cu}$. This was confirmed with the statistical analysis of population of $\mathrm{Cu}$ NPs from TEM micrographs. At lower reducing agent ratios, two phases coexist $\left(\mathrm{Cu}_{2} \mathrm{O}\right.$ and zerovalent $\left.\mathrm{Cu}\right)$ due to incomplete reduction of copper ions by the reducing agent; however, at higher reducing agent ratios, the $\mathrm{Cu}$ NPs consist mainly of zerovalent $\mathrm{Cu}$. Crystallite size and relative particle size of stabilized $\mathrm{Cu}$ NPs showed considerable differences in results and tendencies in respect to TEM analysis. However, the relative particle size values obtained from FT of XRD data agreed well with the histograms from the TEM observations. From FT results, the relative particle size and reducing agent ratio of stabilized $\mathrm{Cu}$ NPs showed an inverse correlation. The incomplete reduction of copper ions at lower reducing agent ratios was also confirmed by DSC studies. FT-IR and 2D-IR correlation spectra analysis suggested the first event involved in the stabilization of $\mathrm{Cu}$ NPs is their electrostatic interaction with $-\mathrm{C}=\mathrm{O}$ of carboxylate groups of $\mathrm{NaAlg}$, followed by the interaction with the available $\mathrm{O}-\mathrm{C}-\mathrm{O}^{-}$, and finally with the $-\mathrm{OH}$ groups. Bacterial susceptibility to stabilized nanoparticles 
was found to vary depending on the bacterial strains. The lowest MIC and MBC of stabilized Cu NPs ranged between $2 \mathrm{mg} / \mathrm{L}$ and $8 \mathrm{mg} / \mathrm{L}$ for all studied strains. Disk-diffusion studies with both $E$. coli strains revealed greater effectiveness of the stabilized Cu NPs compared to the positive controls (cloxacillin, amoxicillin, and nitrofurantoin). S. aureus showed the highest sensitivity to stabilized Cu NPs compared to the other studied strains.

Conclusion: $\mathrm{Cu}$ NPs were successfully synthesized via chemical reduction assisted with microwave heating. Average particle size, polydispersity, and phase composition of $\mathrm{Cu}$ NPs depended mainly on the reducing agent ratio. Likewise, thermal stability and antibacterial activity of stabilized $\mathrm{Cu}$ NPs were affected by their phase composition. Because of the carboxylate groups in polymer chains, the structural changes of stabilized $\mathrm{Cu}$ NPs are different from those of NaAlg. NaAlg acted as a size controller and stabilizing agent of $\mathrm{Cu}$ NPs, due to their ability to bind strongly to the metal surface. Our study on the stabilizing agent-dependent structural changes of stabilized NPs is helpful for wide application of NaAlg as an important biopolymer.

Keywords: stabilized copper nanoparticles, sodium alginate, 2D-IR correlation spectroscopy, antibacterial activity

\section{Introduction}

A major topic in the synthesis of inorganic-organic compounds is the combination of active components. A hybrid material is a material that includes two moieties blended on the molecular scale. ${ }^{1}$ Polymer nanocomposites obtained on the basis of polymers and metal nanostructures are of practical interest today. The integration of nanotechnology and biology provides the opportunity for the development of new nanoscale materials that can be applied to many potential applications in biological science, clinical medicine, and packaging technologies. The post-synthesis stability in terms of shape and size of metal nanoparticles is crucial because the agglomeration of nanoparticles may affect the outcome and interpretation of antibacterial activity results. Dispersed or weakly aggregated nanoparticles in suspension have a more distorted internal structure and different reactivity and rates of surface reactions than strongly aggregated nanoparticles., ${ }^{2,3}$ Such changes in physicochemical properties may alter the interaction of nanoparticles with bacteria, the bactericidal efficiency, viability, and the minimum inhibitory concentration (MIC)/minimum bactericidal concentration (MBC) values. The immobilization of colloidal metal nanoparticles is not only necessary to prevent aggregation but to provide positional stability to the nanoparticles on a surface, or in a structure, after they have been reduced. Polymer matrices would facilitate efficient immobilization of nanoparticles in order to render composite materials with exceptional properties for a wide range of applications. Stabilization with naturally occurring polymers (also called biopolymers) is an alternative in order to avoid, prevent, or mitigate the agglomeration of nanoparticles (controlling the particle size distribution by steric effect) and promote their long-term air and water stabilities. ${ }^{4-7}$

Alginate is a naturally occurring polysaccharide obtained from marine brown algae, comprising the linear chain of $(1,4)-\beta$-D-mannuronic acid and $(1,3)$ - $\alpha$-L-guluronic acid, ${ }^{8}$ which vary in composition and sequence depending on the source of the alginate. Because of its unique properties, including inexpensiveness, biocompatibility, a relatively inert hydrogel environment within the matrix, and a mild room temperature encapsulation process, alginate has attracted intense attention as an important class of biomaterial in recent years. ${ }^{9}$ Alginate could facilitate the complexation of copper ions to their matrix (by decreasing the mobility of the molecular chains), because of the extensive hydroxyl groups on their structure, which provide more inter- and intramolecular interstices that can selectively trap metal nanoparticles. Therefore, the nanoparticles' release and mobility will depend (to some extent) on how these particles are associated to biopolymer.

We therefore performed a study aimed at proposing a correlation between infrared (IR) spectra and molecular structure of stabilized copper nanoparticles (Cu NPs) with sodium alginate $(\mathrm{NaAlg})$. Two-dimensional infrared correlation spectroscopy (2D-IR COS) is a well-established analytical technique that provides considerable utility and benefit in various spectroscopic studies of complex systems. Some of the notable features of generalized 2D correlation spectra are: simplification of complex spectra consisting of many overlapped peaks; enhancement of spectral resolution by spreading peaks along the second dimension and establishment of unambiguous assignments through correlation of bands selectively coupled by various interaction mechanisms. ${ }^{10}$ As well, this paper presents a statistical study based on average nanoparticle size and oxidation states of stabilized $\mathrm{Cu}$ NPs, likewise, comparison between average particle size, crystallite size and relative particle size confirms that the synthesis of NPs assisted with microwave heating yields a size weighted smaller particles, in the order of 3-10 nm.

Recent advances in the design and study of metal nanoparticles have revealed biological activity and structural and functional changes induced in bacterial cells. Particular progress 
has been made in understanding the size, shape, and surface chemistry of metal nanostructures and their influence on biocidal activity. ${ }^{11}$ It has emerged that multiple factors cooperate to establish a specific antibacterial activity, mainly dependent on the high surface atom density of the nanoparticles, which includes their size and shape, ${ }^{12-14}$ particle internalization, ${ }^{15,16}$ agglomeration of metal nanostructures over time on in vitro assays, ${ }^{3,13,17}$ chemical functionalization of nanoparticles, ${ }^{18,19}$ concentration of metal, ${ }^{3}$ types of microorganism and initial number of bacterial cells, ${ }^{3,20,21}$ and type of assay. ${ }^{22} \mathrm{~A}$ secondary aim of this study was to compare the bactericidal effects of stabilized $\mathrm{Cu}$ NPs using various bacterial strains, to reveal strain specificities, and to correlate the phases of composition of $\mathrm{Cu}$ NPs with antibacterial activity, eventually leading to better utilization of nanoparticles for specific applications.

\section{Materials and methods}

\section{Preparation of stabilized Cu NPs}

Copper nitrate $\left(\mathrm{Cu}\left[\mathrm{NO}_{3}\right]_{2}\right)$ and ascorbic acid $\left(\mathrm{C}_{6} \mathrm{H}_{8} \mathrm{O}_{6}\right)$ were obtained from Winkler (Santiago, Chile). Sodium alginate (NaAlg) was obtained from Sigma Aldrich (St Louis, MO). All the reagents were used as received, without further purification, and all the water was nanopure. The synthesis of copper NPs was performed according to Blosi et $\mathrm{al}^{23}$ with modifications, which are reported for the first time herein. The precursor $\left(0.1 \mathrm{M}, \mathrm{Cu}\left[\mathrm{NO}_{3}\right]_{2}\right)$ was completely dissolved in $100 \mathrm{~mL}$ of nanopure water under magnetic stirring. Then this solution was heated to the synthesis temperature $\left(95^{\circ} \mathrm{C}\right)$ in a Thomas microwave oven (TH-17DM, $560 \mathrm{~W}$; Rotho, Würenlingen, Switzerland). Once the synthesis temperature was reached, $50 \mathrm{~mL}$ of ascorbic acid solution (containing the proper quantities of reducing agent) was added to the hot solution and stirred continuously at $60 \mathrm{rpm}$. After ascorbic acid addition, the blue solution turned dark green, thus indicating the immediate nucleation of Cu NPs. Finally, the colloidal dispersions were deposited onto NaAlg by microwave heating for 1 hour $\left(88^{\circ} \mathrm{C}\right)$. The $\mathrm{Cu}\left(\mathrm{NO}_{3}\right)_{2}$ and $\mathrm{NaAlg}$ amount were kept constant for all stabilized $\mathrm{Cu}$ NPs at a molar ratio of 1. The weight loss of stabilized $\mathrm{Cu}$ NPs was measured upon drying until constant weight at $110^{\circ} \mathrm{C}$. Equilibrium moisture content (\%) was calculated as follows:

$$
\text { EMC }(\%)=\left(\frac{\text { Initial sample weight }}{\text { Drysample }}-1\right) \times 100
$$

The synthesis conditions used for producing the different $\mathrm{Cu}$ NPs and stabilized $\mathrm{Cu}$ NPs are summarized in Table 1.

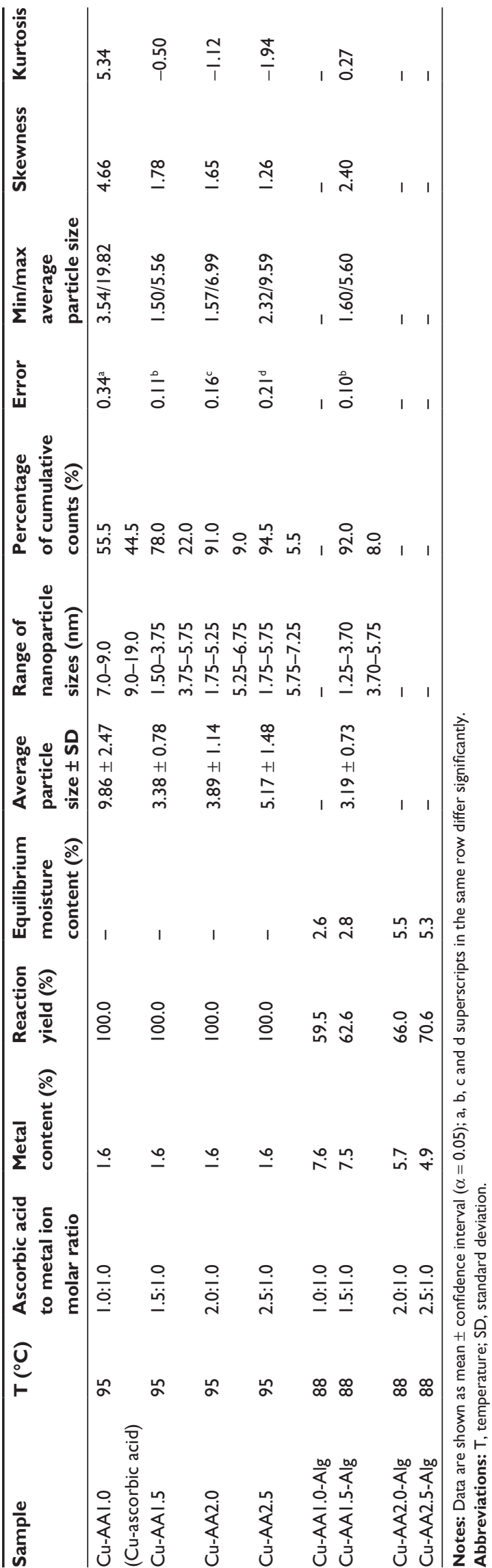




\section{Characterization of Cu NPs}

\section{and stabilized $\mathrm{Cu}$ NPs}

TEM micrographs were obtained using a Jeol (Tokyo, Japan) JEM 1200EXII TEM microscope with 4- $\AA$ resolution. Average particle size, standard deviation, and error shown in Table 1 were calculated on 200 particles by analyzing different micrographs. Histograms were obtained using the OriginLab (Northampton, MA) 8.0 v8.0724 software. An analysis of variance was performed to determine whether the NPs' size differed significantly. A multiple comparison procedure (multiple range test) was then used to find which means were significantly different at the $95 \%$ confidence level. The method used to discriminate among the means was Fisher's least significant difference procedure. All statistics were obtained using Statgraphics Plus 3.1 software (Manugistics, Rockville, MD). X-ray diffraction (XRD) analysis of the stabilized $\mathrm{Cu}$ NPs was performed using a Endeavor diffractometer (D4/MAX-B; Bruker, Karlsruhe, Germany), employing CuK $\alpha$ radiation (at $40 \mathrm{kV}$ and $40 \mathrm{~mA}$ ). Data were obtained over the range $2 \theta=10^{\circ}-80^{\circ}$ using a step size of $0.02^{\circ}$ and counting time of 25 seconds per step. Reference intensity ratios methodology from XRD was used in order to assign the phases observed in the $\mathrm{X}$-ray pattern. The crystallite sizes of stabilized $\mathrm{Cu}$ NPs were calculated using the Scherrer equation as follows:

$$
d=\left(\frac{0.9 \lambda}{\beta \cos \theta}\right)
$$

where $\lambda$ is the wavelength of $\mathrm{Cu} \mathrm{K} \alpha$ radiation (here $\lambda=0.1541 \mathrm{~nm}$ ), B is the calibrated half-width of the peak in radians and $\theta$ is the diffraction angle of the three independent peaks of zerovalent $\mathrm{Cu}$ from the diffraction patterns. The calculated values of crystallite sizes are listed in Table 3. The Fourier method has been also applied to the diffraction data of stabilized $\mathrm{Cu}$ NPs in order to calculate the relative size of stabilized Cu NPs, according to the described by Hall et al. ${ }^{24}$ FT $P(\mathrm{r})$ was calculated using the Origin 8.0 v8.0724 software.

Optical absorption spectra were determined on a PerkinElmer (Waltham, MA) Lambda 35 ultravioletvisible (UV-vis) spectrophotometer at room temperature. Thermogravimetric analysis (TGA) of stabilized $\mathrm{Cu}$ NPs was carried out using a TG 209F3 thermogravimetric analyzer (Netzsch, Selb, Germany). Stabilized Cu NPs were placed in appropriate pans and heated from $35^{\circ} \mathrm{C}$ to $600^{\circ} \mathrm{C}$ at $5^{\circ} \mathrm{C} /$ minute under $\mathrm{N}_{2}$ atmosphere. Differential scanning calorimetry (DSC) studies were conducted on a DSC 204F1
Phoenix differential scanning calorimeter (Netzsch) using an accurately weighed sample $(10 \mathrm{mg})$ in a loosely covered aluminum pan and heated from $50^{\circ} \mathrm{C}$ to $250^{\circ} \mathrm{C}$ at $5^{\circ} \mathrm{C} /$ minute under $\mathrm{N}_{2}$ atmosphere. An empty, loosely covered aluminum pan was used as the reference. The metal content was determined by atomic absorption spectrometry, using a Thermo Solaar M Series AA spectrometer (Thermo Scientific, Waltham, MA).

\section{Fourier transform-infrared (FT-IR), principal component analysis (PCA), and 2D 2D-IR correlation analysis}

The FT-IR spectra (resolution of $4 \mathrm{~cm}^{-1}$ ) were recorded from 4000 to $450 \mathrm{~cm}^{-1}$ and scanned 64 times (transmittance mode), on a Nicolet Nexus spectrometer (Nicolet Instrument, Madison, WI) at room temperature. All spectra were baseline-corrected, smoothed, and normalized on the basis of the internal standard band nearest to $2929 \mathrm{~cm}^{-1}$ due to the $-\mathrm{CH}_{2}$ group, which is not affected by $\mathrm{Cu}$ NPs. The number of peaks involved was determined on the basis of the secondderivative FT-IR spectra for the stabilized $\mathrm{Cu}$ NPs, in the range 3600-800 $\mathrm{cm}^{-1}$. Curve fitting for the peak deconvolution was performed with OriginPro 8.5.1 software (Microcal, Piscataway, NJ) with the Multiple Peak Fit Tool. The shape of the peak from the absorption bands for NaAlg and stabilized $\mathrm{Cu}$ NPs was obtained using Gaussian fit. The reduced chi-squared value for all the deconvoluted curves was $\chi^{2}$ $\geq 0.1$. Prior to PCA calculation, the mean centering operation was applied to the data matrix; only the range between 2000 and $800 \mathrm{~cm}^{-1}$ was considered. PCA was performed using Pirouette 3.11 (Infometrix, Tulsa, OK). The 2D correlation spectroscopy and synchronous and asynchronous maps were calculated according to algorithms described by Noda $^{26}$ and Jung and Noda. ${ }^{25}$ Data processing and analysis were performed using MATLAB version 7.4.0.287 R2007a (MathWorks, Natick, MA).

\section{Evaluation of antibacterial activity}

Staphylococcus aureus (ATCC 6538P), Escherichia coli (ATCC 25922) and Salmonella enterica serovar Typhimurium (ATCC 13311 and 14028) were obtained from the American Type Culture Collection (Manassas, VA). E. coli O157: H7 was obtained from the collection at the Department of Microbiology, Faculty of Biological Sciences, University of Concepcion, Chile. Each strain was stored at $-80^{\circ} \mathrm{C}$ in Luria Bertani broth $(10 \mathrm{~g}$ of tryptone, $5 \mathrm{~g}$ of yeast extract, and $0.5 \mathrm{~g}$ of $\mathrm{NaCl} / \mathrm{L}$ ) supplemented with $20 \%$ glycerol. 


\section{Well-diffusion test}

One milliliter of inocula at $10^{7}$ colony-forming units (CFU)/ $\mathrm{mL}$ was mixed with warm, melted, autoclaved Mueller Hinton agar and poured into separate plates under aseptic conditions. The plates were covered and allowed to cool. As soon as the agar was partly solidified, the plates were inverted and left for 2 hours. When cooled, three equidistant wells were made at the plate. The wells were made by using a $6-\mathrm{mm}$ puncher that was sterilized with alcohol and flame. Stabilized $\mathrm{Cu} \mathrm{Nps}$ were dissolved in sterile water $(32 \mathrm{mg} / \mathrm{L})$ and then pipetted into the different wells in a sterilized environment at $80 \mu \mathrm{L}$ using a micropipette. Cloxacillin, nitrofurantoin, and amoxicillin were used as positive controls. Finally, the plates were incubated for 24 hours at $37^{\circ} \mathrm{C}$. The inhibition effect was verified by the presence of inhibition zones around the well where the solution was deposited and sized for analysis and comparison.

\section{Minimum inhibitory and bactericidal concentrations}

The MIC and MBC were determined by the broth macrodilution method ${ }^{27}$ in $1 \mathrm{~mL}$ of Mueller Hinton broth. Stabilized $\mathrm{Cu}$ NPs were dissolved in sterile water and added to the broth at concentrations of $1,2,4,8,16,32$, and $64 \mathrm{mg} / \mathrm{L}$. The starting bacterial inocula were $1-5 \times 10^{5} \mathrm{CFU} / \mathrm{mL}$, and bacterial populations were monitored at 24 hours by CFU counts on Mueller Hinton agar plates after incubation at $37^{\circ} \mathrm{C} \pm 2^{\circ} \mathrm{C}$. All tests were performed in duplicate.

\section{Results and discussion Morphology of Cu NPs}

The average particle size distribution of $\mathrm{Cu}$ NPs was randomly measured, and the obtained data are represented by histograms in Figure 1. In general, the morphology of the $\mathrm{Cu}$ NPs is of spherical shape.
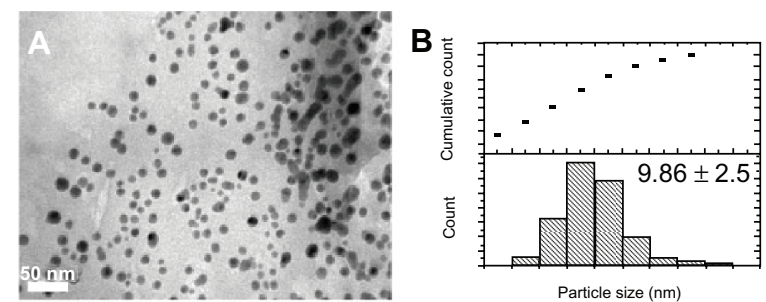

Particle size $(\mathrm{nm})$
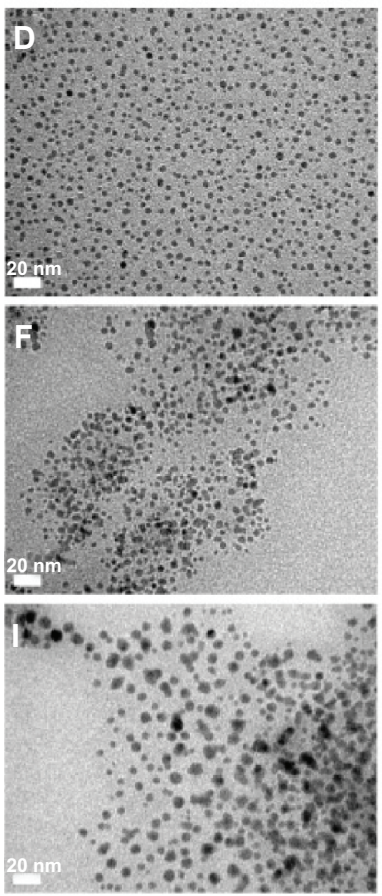

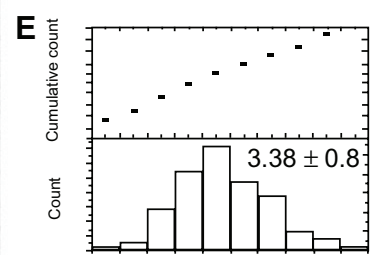

Particle size $(\mathrm{nm})$
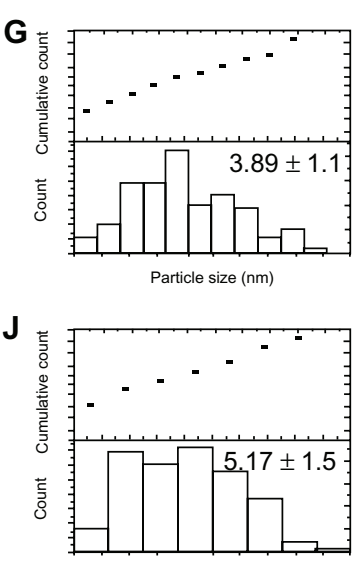

Particle size $(\mathrm{nm})$
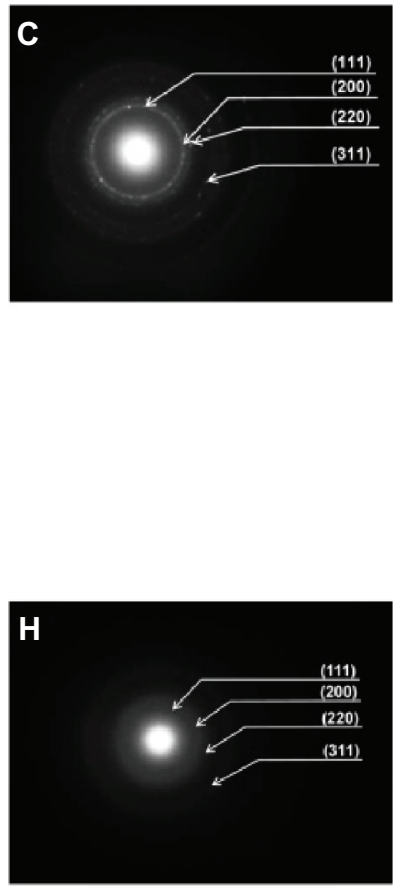

K

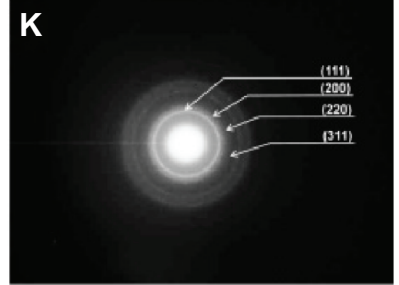

Figure I TEM micrographs of Cu-AAI.0, Cu-AAI.5, Cu-AA2.0 and Cu-AA2.5 NPs, respectively (A, D, F and I); histograms and cumulative counts of particle size of Cu NPs (B, E, G and J); selected area electron diffraction of Cu-AAI.0, Cu-AA2.0, and Cu-AA2.5 NPs, respectively(C, $\mathbf{H}$ and $\mathbf{K})$.

Abbreviation: Cu NP, copper nanoparticles. 
Cu-AA1.0 NPs showed a fairly uniform distribution of well-formed $\mathrm{Cu}$ NPs (Figure 1A). More than $50 \%$ of these nanoparticles fall within the size range of 3-9 $\mathrm{nm}$ in diameter (Figure 1B). The average particle size is around $9.86 \mathrm{~nm}$ with large dispersity ( $49.0 \%)$. Figure 1C shows the corresponding selected area electron diffraction (SAED) of Cu-AA1.0 NPs. Four fringe patterns with plane distances of $2.080( \pm 0.003), 1.844( \pm 0.020), 1.262( \pm 0.013)$, and 1.091 $( \pm 0.011) \AA$ can be observed in the SAED pattern (Figure 1C). They are related to the (1 111$),\left(\begin{array}{lll}2 & 0 & 0\end{array}\right),\left(\begin{array}{lll}2 & 2 & 0\end{array}\right)$, and ( $\left.\begin{array}{lll}3 & 1 & 1\end{array}\right)$ planes of face-centered cubic copper.

As the reducing agent ratio increased to 1.5 , the polydispersity decreased significantly to $15.5 \%$. After this ratio, the average particle size and the size dispersion did not change very much. The TEM micrograph for Cu-AA1.5 NPs revealed well-distributed $\mathrm{Cu} N P$ s with sizes less than $3.4 \mathrm{~nm}$ (Figure 1D and E). It is important to note that the electron diffraction for the Cu-AA1.5 NPs (Figure 1F) cannot be obtained probably due to their finer size. ${ }^{28}$ The average particle size of the $\mathrm{Cu}$-AA2.0 NPs (Figure 1F) appears to be similar to $\mathrm{Cu}-\mathrm{AA} 1.5 \mathrm{NPs}$, ie, about $3.89 \mathrm{~nm}$ in diameter $(\sim 14.0 \%$ of dispersity, Figure $1 \mathrm{G})$; however, there is a statistically significant difference between the average particle size for all $\mathrm{Cu}$ NPs $(P<0.05)$.

The average particle size of $\mathrm{Cu}-\mathrm{AA} 2.5 \mathrm{NPs}$ was found to be $5.17 \mathrm{~nm}$ (Figure 1I and J), with low dispersity ( 12.5\%). Similar behavior was observed for $\mathrm{Cu}-\mathrm{AA} 1.5$ and $\mathrm{Cu}-$ AA2.0 NPs; almost $30 \%$ of the average particle sizes fell within the range of 3.3-4.4 nm. From the SAED patterns $(2,065[ \pm 0.0106], 1.817[ \pm 0.0053]$, and 1.280 [ \pm 0.00149$])$, and it was confirmed that the $\mathrm{Cu}-\mathrm{AA} 2.5 \mathrm{NPs}$ consist of facecentered cubic copper (Figure 1K).

The average size of the nanoparticle from TEM stayed within a very small range of the average, as indicated by the small error (Table 1). This indicates that the reducing agent provides good control over the average particle size, which is desired in nanoparticle synthesis. Statistical descriptive analysis of particle size of $\mathrm{Cu}$ NPs suggests that the statistical skewness (a measure of data asymmetry) was positively skewed. The positive skewness of data indicates an increased number of finer nanoparticles in the distribution. This result agrees with the results obtained by the semiquantitative weight percentage composition of copper species (Table 2).

Statistical kurtosis of particle size (a measure of peakedness of distribution), indicates that the distribution of Cu-AA1.0 NPs is extremely leptokurtic. A leptokurtic distribution suggests that the $\mathrm{Cu}$ NPs are more singular in size, that is, the range in size is small and the least dimension of the individual nanoparticle is closer to the average particle size. This distribution was not observed from the statistical kurtosis in the other $\mathrm{Cu}$ NPs, which have very platykurtic distributions. A platykurtic distribution indicates that the range between the smallest and largest average nanoparticle size becomes wider as the distribution becomes flatter. The least dimension of the individual nanoparticle deviates quite significantly from the average least dimension.

\section{XRD of stabilized Cu NPs}

XRD patterns of NaAlg and stabilized $\mathrm{Cu}$ NPs are shown in Figure 2. Pure sodium alginate indicated the presence of a completely amorphous material. The broad characteristic diffraction peak of $\mathrm{NaAlg}$ appears at $2 \theta=42.5^{\circ}$ in all curves. The XRD results revealed that $\mathrm{Cu}-\mathrm{AA} 1.0 \mathrm{NPs}$ consist of zerovalent $\mathrm{Cu}$ and $\mathrm{Cu}_{2} \mathrm{O}$, in agreement with the SAED pattern of Figure 1C. The peaks at (111, 42.9132), (200, 50.0289), and $(220,73.7236)$ planes belong to the $\mathrm{fcc} \mathrm{Cu}^{0}$ (JCPDS, PDF, file no 85-1326). ${ }^{29}$ The other peaks at $(111,36.0921)$, $(200,49.9132)$, and $(311,73.7236)$ planes correspond to the primitive cubic $\mathrm{Cu}_{2} \mathrm{O}$ (JCPDS, PDF, File No 77-0199). ${ }^{30}$ The coexisting $\mathrm{Cu}_{2} \mathrm{O}$ is considered to be due to the incomplete reduction of copper ions by the reducing agent. On

Table 2 Peak position, Miller indices (hkl) and semiquantitative weight percentage composition

\begin{tabular}{|c|c|c|c|c|c|c|}
\hline \multirow[b]{2}{*}{ Cu-AAI.0-Alg } & \multirow{2}{*}{$\begin{array}{l}\text { Standard diffraction angle } \\
\text { [20 in degrees] (JCPDS copper) } \\
\mathrm{Cu}^{0}(85-1326)\end{array}$} & \multicolumn{3}{|c|}{ Peak position $2 \theta$ and hkl } & \multirow{2}{*}{$\begin{array}{l}\mathbf{R I R} \\
8.860\end{array}$} & \multirow{2}{*}{$\begin{array}{l}\text { Semiquantitative } \\
\text { wt } \% \text { composition } \\
32 \%\end{array}$} \\
\hline & & $42.9132(111)$ & $50.0289(200)$ & $73.7236(220)$ & & \\
\hline & $\mathrm{Cu}_{2} \mathrm{O}(77-0199)$ & $36.0921(111)$ & $42.9132(200)$ & $73.7236(311)$ & 8.280 & $68 \%$ \\
\hline \multirow[t]{2}{*}{ Cu-AAI.5-Alg } & $\mathrm{Cu}^{0}(85-1326)$ & $43.2635(\mathrm{III})$ & $50.3985(200)$ & $74.0184(220)$ & 8.860 & $84 \%$ \\
\hline & $\mathrm{Cu}_{2} \mathrm{O}(77-0199)$ & $36.3997(\mathrm{III})$ & $43.2635(200)$ & $74.0184(311)$ & 8.280 & $16 \%$ \\
\hline \multirow[t]{2}{*}{ Cu-AA2.0-Alg } & $\mathrm{Cu}^{0}(85-1326)$ & $43.2715(111)$ & $50.3895(200)$ & $74.0556(220)$ & 8.860 & $91 \%$ \\
\hline & $\mathrm{Cu}_{2} \mathrm{O}(77-0199)$ & $36.4517(111)$ & $43.27 I 5(200)$ & $74.0556(311)$ & 8.280 & $9 \%$ \\
\hline \multirow[t]{2}{*}{ Cu-AA2.5-Alg } & $\mathrm{Cu}^{0}(85-1326)$ & $43.2199(111)$ & $50.3410(200)$ & $74.0448(220)$ & 8.860 & $93 \%$ \\
\hline & $\mathrm{Cu}_{2} \mathrm{O}(77-0199)$ & $36.450 \mathrm{I}(\mathrm{III})$ & $43.2199(200)$ & $74.0448(311)$ & 8.280 & $7 \%$ \\
\hline
\end{tabular}

Abbreviation: RIR, reference intensity ratio. 


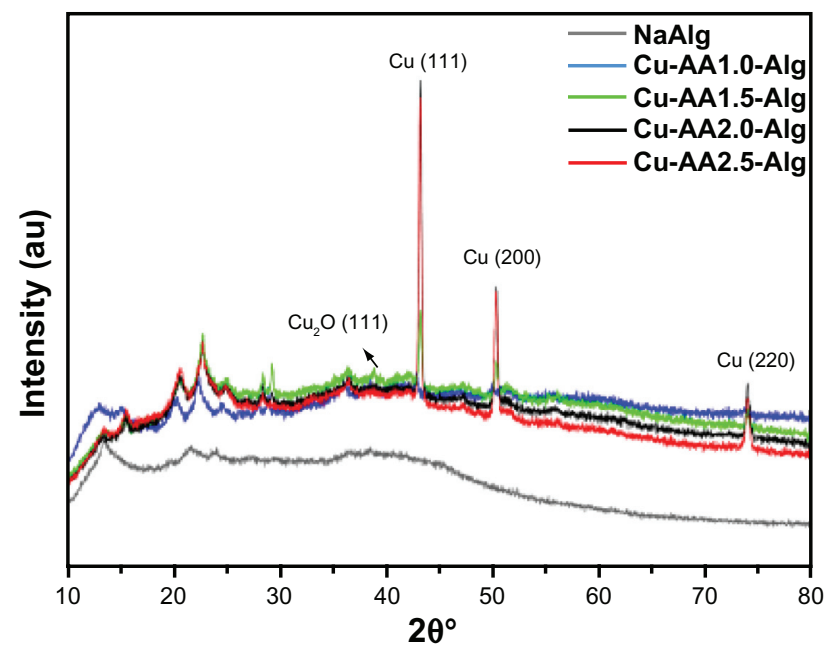

Figure 2 X-ray diffraction patterns of the stabilized copper nanoparticles.

the other hand, $\mathrm{Cu}-\mathrm{AA} 1.5, \mathrm{Cu}-\mathrm{AA} 2.0$, and $\mathrm{Cu}-\mathrm{AA} 2.5 \mathrm{NPs}$ consist mainly of zerovalent $\mathrm{Cu}$ plus a small amount of $\mathrm{Cu}_{2} \mathrm{O}$ (Table 2). Note that the widths of the diffraction peaks of $\mathrm{Cu}^{0}$ increase with increasing the reducing agent ratio, which indicates a decreasing of the particle size of stabilized $\mathrm{Cu}$ NPs nanoparticles.

A semiquantitative analysis of the weight percentage composition of stabilized $\mathrm{Cu}$ NPs was performed with the software package X'pert HighScore v.1.0a (Philips Analytical, Almelo, Netherlands) by the reference intensity ratios method. This standardless method relies on the $\mathrm{I} / \mathrm{I}_{\text {cor }}$ values, which are unique to the individual phases and indicate the ability of the material to diffract X-rays with respect to that of corundum. ${ }^{31}$ Indexing data and approximate compositions of the phases are summarized in Table 2. As can be seen in Table 2, there is a direct correlation between the reducing agent ratio and the percentage of zerovalent $\mathrm{Cu}$. When the reducing agent ratio is more than 1.5 , there are mostly zerovalent $\mathrm{Cu}$ diffraction peaks in the XRD patterns. However, at lower reducing agent ratios, the $\mathrm{Cu}_{2} \mathrm{O}$ percentage dominates over that of zerovalent copper. Thus, this can be a possible reason for the large polydispersity in the particle size of $\mathrm{Cu}-\mathrm{AA} 1.0$.

The crystallite size and particle size of stabilized $\mathrm{Cu}$ NPs were also determined by using the Scherrer formula ${ }^{32}$ and the $\mathrm{FT}^{26}$ from XRD data (Table 3). According to several authors, ${ }^{33-35}$ the Scherrer formula cannot be applied to nanoparticle samples, because of overlapping peaks of DRX, the presence of noncrystalline structures in the samples, and when the relative mean sizes of distributions of nanocrystals are broad. ${ }^{34}$ As follows from Table 3, there is a discrepancy between the crystallite size values obtained from the Scherrer formula and histograms from TEM observations. However, the relative particle size values obtained from FT of XRD data agree well with the histograms from the TEM observations. From FT results, the stabilized $\mathrm{Cu}$ NPs varied approximately $5.4-7.5 \mathrm{~nm}$ in size by varying the reducing agent ratio. Moreover, from the FT results, it is possible to confirm the correlation between the decrease in particle size and the increase in reducing agent ratio. The slight differences in the particle size of $\mathrm{Cu}$ NPs when using NaAlg as stabilizer are probably due to the ability of $\mathrm{NaAlg}$ to bind strongly to the metal surface (interaction of $-\mathrm{C}-\mathrm{O}$ groups of NaAlg with $\mathrm{Cu}^{0}$ and $\mathrm{Cu}^{2+}$ ) with the consequent inhibition of particle growth by collision.

Table 3 Crystallite size and relative particle size of stabilized copper nanoparticles (Cu NPs) calculated from Scherrer equation and Fourier transform (FT) of diffraction data

\begin{tabular}{|c|c|c|c|c|c|c|c|c|}
\hline & \multirow[t]{2}{*}{ Hkl } & \multirow[t]{2}{*}{$\begin{array}{l}\text { Peak } \\
\text { position } 2 \theta\end{array}$} & \multirow[t]{2}{*}{$\operatorname{Cos}(\theta)$} & \multirow[t]{2}{*}{$\begin{array}{l}\text { FWHM } \\
\text { (radians) }\end{array}$} & \multirow[t]{2}{*}{$\begin{array}{l}\text { Crystallite } \\
\text { size }(n m)\end{array}$} & \multicolumn{2}{|c|}{$\begin{array}{l}\text { Analysis of Scherrer } \\
\text { diffraction data }\end{array}$} & \multirow{2}{*}{$\begin{array}{l}\text { Relative particle size } \\
\text { of stabilized Cu NPs } \\
\text { by FT (nm) }\end{array}$} \\
\hline & & & & & & $\begin{array}{l}\text { Mean crystallite } \\
\text { size }(\mathrm{nm})\end{array}$ & $\begin{array}{l}\text { Smoothed } \\
\text { data }(\mathrm{nm})\end{array}$ & \\
\hline \multirow[t]{3}{*}{ Cu-AAI.0-Alg } & (III) & 42.913 & 0.93070 & $0.002747 \mid$ & 53.626 & $32.9 \pm 24.6$ & $14.67 \pm 1.79$ & $7.48 \pm 0.2$ \\
\hline & (200) & 50.029 & 0.90620 & $0.004 \mid 225$ & 36.702 & & & \\
\hline & (220) & 73.724 & 0.80009 & 0.0201062 & 8.5232 & & & \\
\hline \multirow[t]{3}{*}{ Cu-AAI.5-Alg } & (III) & 43.263 & 0.92957 & 0.0024051 & 61.328 & $52.2 \pm 8.6$ & $14.57 \pm 1.67$ & $5.96 \pm 0.3$ \\
\hline & (200) & 50.398 & 0.90483 & 0.0034348 & 44.116 & & & \\
\hline & (220) & 74.018 & 0.79854 & 0.0033510 & 51.238 & & & \\
\hline \multirow[t]{3}{*}{ Cu-AA2.0-Alg } & (III) & $43.27 \mid$ & 0.92955 & 0.002405 I & 61.330 & $62.5 \pm 19.0$ & $13.93 \pm 0.56$ & $6.24 \pm 0.2$ \\
\hline & (200) & 50.389 & 0.90487 & 0.0034348 & 44.115 & & & \\
\hline & (220) & 74.056 & 0.79834 & 0.0020944 & 82.001 & & & \\
\hline \multirow[t]{3}{*}{ Cu-AA2.5-Alg } & (III) & 43.220 & $0.9297 \mid$ & 0.0034348 & 42.936 & $37.4 \pm 7.2$ & $|4.2| \pm 1.08$ & $5.396 \pm 0.2$ \\
\hline & (200) & 50.341 & 0.90505 & 0.0037786 & 40.092 & & & \\
\hline & (220) & 74.045 & 0.79840 & 0.0058643 & 29.284 & & & \\
\hline
\end{tabular}

Abbreviations: FWHM, full width at high maximum intensity; Hkl, Miller indices (Hkl); Cos, Cosine. 
Zhu et $\mathrm{al}^{36}$ explained the influence of reducing agent ratio on the formation of copper nanoparticles. In this paper, the authors indicate that at low reducing agent ratios, the reduction rate of copper sulphate is slow and only few nuclei of copper can be formed in the early period of the reduction. The atoms formed at that period might participate mainly in collision with already formed nuclei, instead of the formation of new nuclei, so the particle size was larger. As the reducing agent is increased, the percentage of zerovalent copper increases. However at a lower reducing agent ratio, the $\mathrm{Cu}_{2} \mathrm{O}$ percentage dominates over that of zerovalent copper. During the reduction with lower reducing agent ratio (1.0\%), the particles had large size dispersion (49\%). Increasing the ratio of ascorbic acid to $1.5 \%$ decreased polydispersity significantly to $15.5 \%$. After this ratio, the average particle size and the size dispersion did not change very much.

According to Bönnemann et $\mathrm{al}^{37}$ and Patakfalvi et $\mathrm{al}^{38}$, the nucleation of metal nanoparticles by reduction technique is an autocatalytic process: a slow, continuous nucleation is followed by rapid, autocatalytic particle growth. The steric stabilization by the large molar ratio of NaAlg (supersaturation) at the first step in the chemical reduction is the probable reason for the formation of $\mathrm{Cu}$ NPs of smaller size. The extensive carboxylate and hydroxyl groups on the polymer matrix could provide more inter- and intramolecular interstices, which will selectively trap the Cu NPs formed.

\section{UV-vis absorption}

The UV-vis absorbance spectra of $\mathrm{Cu}$ NPs in water are shown in Figure 3A. At first, the precursor solution was blue, a typical feature of copper nitrate, with a weak and narrow visible absorption peak at $559 \mathrm{~nm}$. For the $\mathrm{Cu}$ NPs, no absorption in the visible range is observed, while distinct broad bands are observed at $264,280,288$, and $295 \mathrm{~nm}$, according to Mie's theory (dipole oscillation). ${ }^{39}$ The increase in the intensity of the peak around the maximum value could be attributed to the increasing concentration of the reducing agent. The exact position of the plasmon absorption depends on stability ( $\mathrm{pH}$, solvent type, and stabilizing agent) and particle size. ${ }^{4,40}$ In this case, $\mathrm{Cu}$ NPs showed no surface plasmon resonance, as shown in Figure 3A. This could be a consequence of a combination of small particle size or a thin copper oxide layer around the copper nanoparticles. ${ }^{41,42}$ Usually, for $\mathrm{Cu}$ NPs ranging between 10 and $40 \mathrm{~nm}$ in diameter, the plasmon resonance appears around $560 \mathrm{~nm}^{4,40}$; however, the absorption spectra of small metal particles (diameter $<20 \mathrm{~nm}$ ) depend only on the dipole oscillation and do not evidence surface plasmon resonance. These results are consistent with reports for the $\mathrm{Cu}$ NPs in polar solvents. ${ }^{43,44}$

With the stabilizing agent (Figure 3B), the UV spectra were shifted to lower wavelengths $(\sim 260,272,273$, and $279 \mathrm{~nm}$ ). This shift is probably due to the slight reduction of particle size by using NaAlg as stabilizer. NaAlg has the structure of pyranose skeleton with carboxylate ions and oxygen polar groups, which donate lone-pair electrons forming a coordinative interaction with the zerovalent $\mathrm{Cu}$, inhibiting the particle growth by collision. NaAlg acts as size controller, hindering the metal nuclei from the aggregation.

\section{Thermal characterization}

The results of thermogravimetric measurements carried out for stabilized $\mathrm{Cu}$ NPs are summarized in Table 4. All stabilized $\mathrm{Cu}$ NPs and NaAlg started decomposing below $100^{\circ} \mathrm{C}$, but the rapid degradation was started at around $165^{\circ} \mathrm{C}$. Two mass losses are identified, as reflected in two peaks in the differential thermal analysis curves (Figure 4). The first thermal event over $100^{\circ} \mathrm{C}$ may be attributed to the vaporization of physisorbed water from stabilized $\mathrm{Cu}$ NPs. ${ }^{45,46}$ The second thermal event, starting over $160^{\circ} \mathrm{C}$, was because of NaAlg degradation. ${ }^{47,48}$ The weight loss between $160^{\circ} \mathrm{C}$ and $230^{\circ} \mathrm{C}$ was very fast and
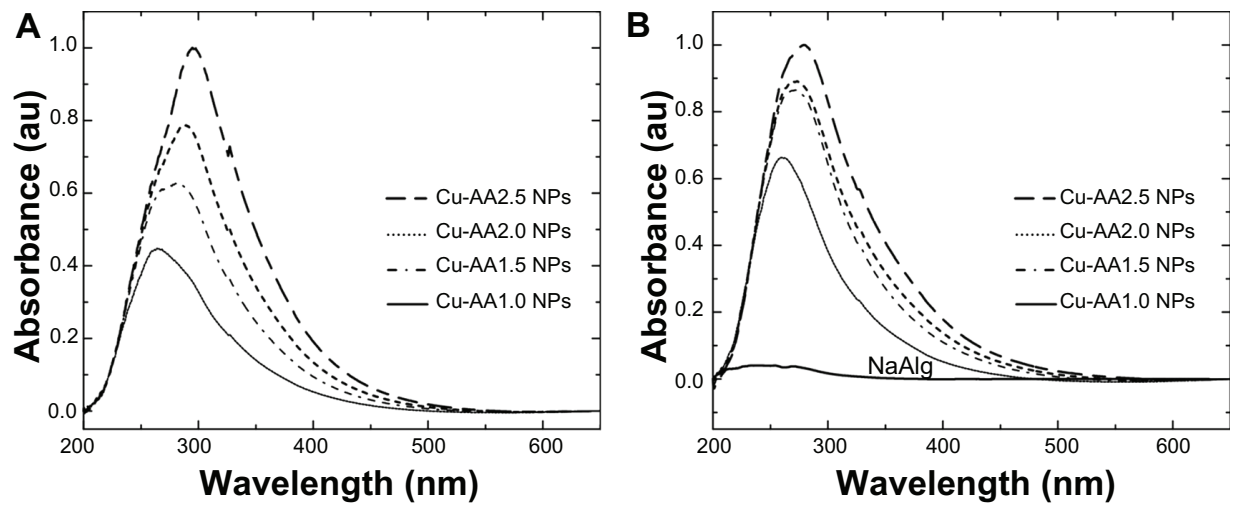

Figure 3 Ultraviolet-visible (UV-vis) spectra of copper nanoparticles (NPs) (A); UV-vis spectra of stabilized copper NPs (B). 
Table 4 Thermal behavior of stabilized copper nanoparticles

\begin{tabular}{|c|c|c|c|c|c|c|c|c|c|}
\hline & \multicolumn{2}{|c|}{$\mathbf{T}_{\mathrm{dl}}\left({ }^{\circ} \mathrm{C}\right)$} & \multirow{2}{*}{$\begin{array}{l}\text { Weight } \\
\text { loss (\%) }\end{array}$} & \multicolumn{2}{|c|}{$\mathbf{T}_{\mathrm{d} 2}\left({ }^{\circ} \mathrm{C}\right)$} & \multirow{2}{*}{$\begin{array}{l}\text { Weight } \\
\text { loss (\%) }\end{array}$} & \multicolumn{2}{|c|}{$\mathrm{T}_{\mathrm{d} 3}\left({ }^{\circ} \mathrm{C}\right)$} & \multirow{2}{*}{$\begin{array}{l}\text { Weight } \\
\text { loss (\%) }\end{array}$} \\
\hline & $\mathbf{T}_{\text {onset }}$ & $\mathbf{T}_{\max }$ & & $\mathbf{T}_{\text {onset }}$ & $\mathbf{T}_{\max }$ & & $\mathbf{T}_{\text {onset }}$ & $\mathbf{T}_{\max }$ & \\
\hline $\mathrm{NaAlg}$ & $100.0^{45}$ & $177.4^{45}$ & $24.3^{45}$ & $200.0^{45}$ & $229.0^{45}$ & $30.8^{45}$ & - & - & - \\
\hline Cu-AAI.0-Alg & 112.5 & 142.5 & 8.1 & 167.5 & 217.5 & 21.8 & 237.5 & 247.5 & 13.4 \\
\hline Cu-AAI.5-Alg & 93.0 & 148.0 & 9.3 & 163.0 & 218.0 & 20.4 & - & - & - \\
\hline Cu-AA2.0-Alg & 73.2 & 143.2 & 6.9 & 158.2 & 218.2 & 21.4 & - & - & - \\
\hline Cu-AA2.5-Alg & 102.3 & 142.3 & 9.6 & 162.3 & 222.3 & 24.2 & - & - & - \\
\hline
\end{tabular}

may be related to the biopolymer degradation. It is noteworthy to say that $\mathrm{Cu}$ NPs did not increase the thermal stability of the stabilized Cu NPs. All stabilized Cu NPs showed a decrease of $\mathrm{T}_{\mathrm{d} 2}$ due to the loss of interpolymer chain interactions during the incorporation of $\mathrm{Cu}$ NPs in the polymer matrix. Similar findings were reported by Cárdenas et $\mathrm{al}^{49}$ by incorporation of $\mathrm{Cu}$ NPs in chitosan matrix.

The differential scanning calorimetry (DSC) curves of stabilized Cu NPs are shown in Figure 5, where two different peaks are observed. Table 5 presents the endothermic and exothermic peaks and enthalpies associated with each peak for stabilized copper nanoparticles. Stabilized $\mathrm{Cu}$ NPs exhibited a weak endothermic transition (low energy) centered at about $100^{\circ} \mathrm{C}$. This peak is attributed to the loss of water associated with the hydrophilic groups of the NaAlg and removal of residual water adsorbed to stabilized nanoparticles. This result was confirmed with the TGA experiments. The major intense peaks recorded in the DSC curves are exothermic transitions $\left(150^{\circ} \mathrm{C}-210^{\circ} \mathrm{C}\right)$. The exothermic peaks resulted from decomposition reactions most probably to the partial decarboxylation of the mannuronic and gluluronic units of $\mathrm{NaAlg}$, depolymerization, pyrolysis of the biopolymer, and oxidation reactions of the copper NPs. Pathak et $\mathrm{al}^{47}$ and Soares et $\mathrm{al}^{50}$ also reported that the thermal degradation of

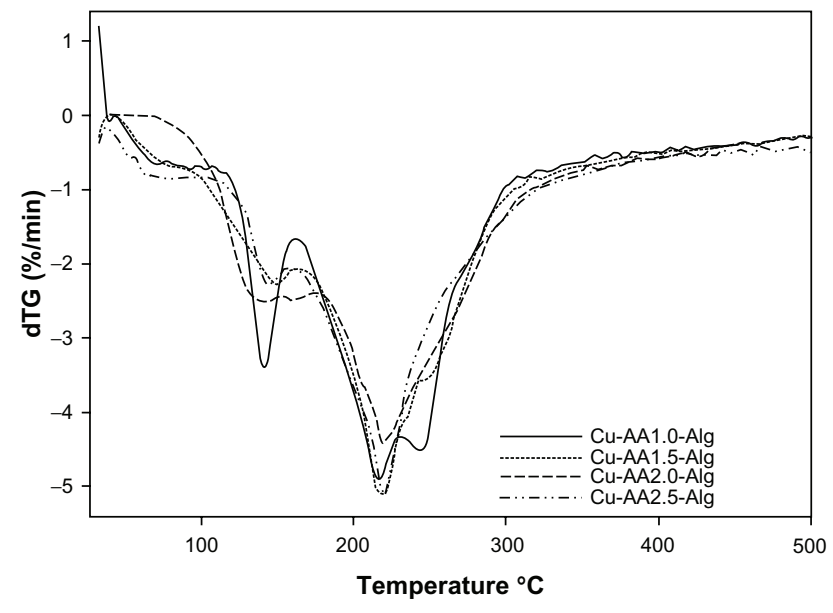

Figure 4 Differential thermal analysis curves of stabilized copper nanoparticles.
$\mathrm{NaAlg}$ begins at $220^{\circ} \mathrm{C}-240^{\circ} \mathrm{C}$. As expected, the exothermic enthalpy values of stabilized nanoparticles increased as the reducing agent ratio was increased. Only $\mathrm{Cu}-\mathrm{AA} 1.0-\mathrm{Alg}$ showed two exothermic transitions peaking at 129.7 and $158.7^{\circ} \mathrm{C}$ (Figure 5). The first exothermic peak is probably attributed to the considerable oxidation process of $\mathrm{Cu}_{2} \mathrm{O}$ (major percentage of composition) to $\mathrm{CuO}$, favored over the formation of copper carbonates. Similar findings were reported by Wang et al. ${ }^{46}$ Also, the oxidation of NaAlg with or without ring opening could take place for all stabilized $\mathrm{Cu}$ NPs. This can be explained by the oxidation of secondary alcohol groups of NaAlg to keto groups (without ring opening) and to dialdehyde or dicarboxylate derivatives (with ring opening). These oxidations could be related to molecular rearrangements and to the high enthalpy values observed but not with weight loss (Table 4).

\section{One-dimensional FT-IR analysis}

FT-IR spectra of stabilized $\mathrm{Cu}$ NPs are shown in Figure 6. In an attempt to overcome the difficulties arising from the strong overlap of the bands of interest for elucidation of the molecular structure of stabilized $\mathrm{Cu}$ NPs, secondderivative spectra and curve-fitting (deconvolution) techniques have been used (Figure 7). In the $3600-2800-\mathrm{cm}^{-1}$ region,

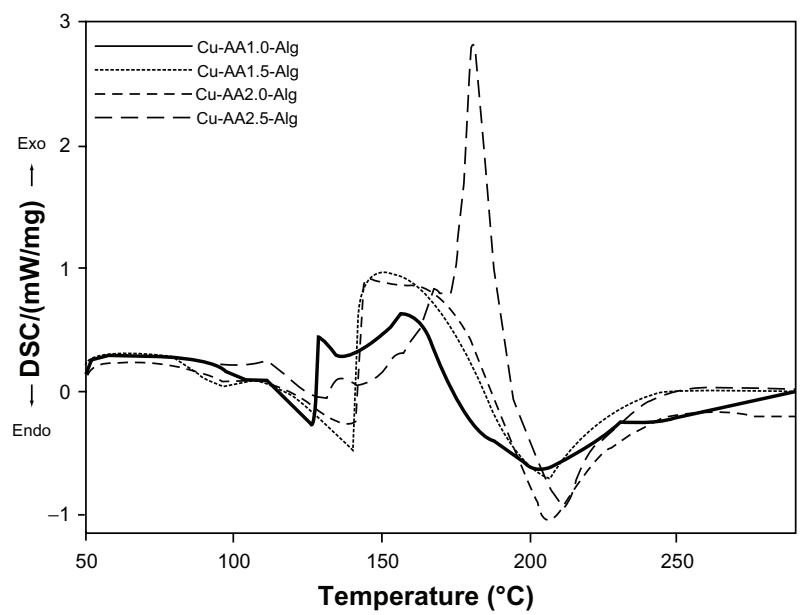

Figure 5 DSC curves of stabilized copper nanoparticles. 
Table 5 Melting temperature and heat of fusion of the stabilized nanoparticles analyzed by DSC

\begin{tabular}{lcclc}
\hline & \multicolumn{4}{c}{ Temperature $\left({ }^{\circ} \mathbf{C}\right)$} \\
\cline { 2 - 5 } & Onset & Peak & Endset & $\Delta \boldsymbol{H}(\mathbf{J} / \mathbf{g})$ \\
\hline Cu-AAI.0-Alg & 82.7 & 106.7 & 107.7 & -1.6 \\
& 126.7 & 129.7 & 134.7 & 17.5 \\
& 134.7 & 158.7 & 200.7 & 89.2 \\
Cu-AAI.5-Alg & 64.3 & 96.3 & 100.3 & -7.1 \\
& 139.3 & 147.3 & 203.3 & 350.5 \\
Cu-AA2.0-Alg & 71.3 & 100.3 & 105.3 & -5.5 \\
& 137.3 & 146.3 & 205.3 & 376.7 \\
Cu-AA2.5-Alg & 81.2 & 102.2 & 109.2 & -2.8 \\
& 143.2 & 181.1 & 210.2 & 452.4 \\
\hline
\end{tabular}

Abbreviation: DSC, differential scanning calorimetry.

strong hydrogen-bonded $(\mathrm{O}-\mathrm{H})$ stretching absorptions and weak $\mathrm{C}-\mathrm{H}$ stretching absorptions are observed in Figure 7. Intermolecular (primary hydroxyl groups) and intramolecular hydrogen bonds are considered to cause the broadening of the -OH band in the FT-IR spectra. A broad band with a maximum around $3439 \mathrm{~cm}^{-1}$ was observed in the spectra of NaAlg (Figure 7A), corresponding to the stretching of $-\mathrm{OH}$ bond of mannuronic and gluluronic units (pyranose rings). ${ }^{51,52} \mathrm{~A}$ shift from 3439 to $3420 \mathrm{~cm}^{-1}$ is observed for stabilized $\mathrm{Cu}$ NPs; this decrease in frequency may occur due to the interaction of $\mathrm{Cu}^{0}$ with $-\mathrm{OH}$ groups (Figure $7 \mathrm{C}$ and $\mathrm{E}$ ).

Bands at $2925 \mathrm{~cm}^{-1}$ and around $2850 \mathrm{~cm}^{-1}$ correspond to asymmetric and symmetric $-\mathrm{C}-\mathrm{H}$ intramolecular bonds..$^{51,52}$ The intensities of both bands increase with the increasing of reducing agent ratio. More intense $-\mathrm{CH}_{2}$ asymmetric bands are because of the dipole moment variation produced by electrostatic interaction of zerovalent $\mathrm{Cu}$ (electron acceptor) and oxygen (electron donor).

In accordance with the literature,,$^{53,54}$ deconvolution was made on the basis of a Gaussian shape. Bands corresponding to the stretching vibration of free $-\mathrm{C}=\mathrm{O}$ groups and

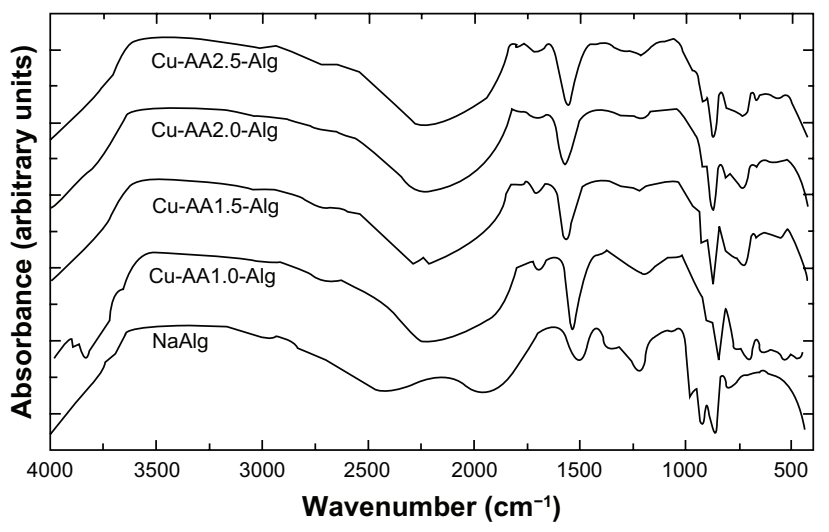

Figure 6 Fourier transform infrared spectroscopy spectra of $\mathrm{NaAlg}$ and stabilized copper nanoparticles. the asymmetric stretching of $-\mathrm{O}-\mathrm{C}-\mathrm{O}^{-}$in $\mathrm{NaAlg}^{55}$ were deconvoluted into three bands by curve fitting. The peak positions of the three deconvoluted bands were 1739, 1645, and $1601 \mathrm{~cm}^{-1}$ (Figure 7B). A noticeable feature in the IR spectra of stabilized $\mathrm{Cu}$ NPs is the shift of $1645 \mathrm{~cm}^{-1}$ to higher frequencies $\left(1681 \mathrm{~cm}^{-1}\right)$ with increasing of the reducing agent ratio (Figure 7D and F). Frequencies below $1500 \mathrm{~cm}^{-1}$ in carbohydrates are due to mixed modes, and every band results from the contribution of more than one kind of motion..$^{56,57}$ The second derivative spectra of the stabilized $\mathrm{Cu}$ NPs in the region of $-\mathrm{C}-\mathrm{OH}$ deformation with contribution of $-\mathrm{O}-\mathrm{C}-\mathrm{O}^{-}$symmetric stretching showed two well-resolved bands, which were shifted to higher frequencies, around 1487 and $1425 \mathrm{~cm}^{-1}$. These bands occur at lower frequency for NaAlg (1464 and $\left.1417 \mathrm{~cm}^{-1}\right)$. This can result from the electrostatic interaction between carboxylate ions and $\mathrm{Cu}^{0}$ and the high electron density induced by $\mathrm{Cu}$ NPs onto the adjacent hydroxyl groups. ${ }^{58} \mathrm{~A}$ weak shoulder in the normal mode corresponding to symmetric stretching of carboxylate ion was observed at $1373 \mathrm{~cm}^{-1}$ for NaAlg. ${ }^{33}$ This peak was more prominent and was shifted to higher frequencies for all stabilized $\mathrm{Cu}$ NPs. The second-derivative spectra of stabilized $\mathrm{Cu}$ NPs suggest that there are at least two bands contributing to the profile, at 1383 and $1344 \mathrm{~cm}^{-1}$.

The $-\mathrm{C}-\mathrm{C}-\mathrm{H}$ deformation at $1302 \mathrm{~cm}^{-1}$, observed as a weak peak in the normal mode, was shifted to higher frequencies for stabilized $\mathrm{Cu}$ NPs in respect to the NaAlg. In the second-derivative spectra, this band was more prominent for NaAlg but remained weak for stabilized Cu NPs.

NaAlg was the only one that showed a weak band in the derivative spectra, corresponding to the $-\mathrm{C}-\mathrm{O}-$ and $-\mathrm{C}-\mathrm{O}-\mathrm{C}-$ stretching at $1255 \mathrm{~cm}^{-1} .{ }^{59} \mathrm{The}-\mathrm{C}-\mathrm{C}-$ stretching and $-\mathrm{C}-\mathrm{C}-\mathrm{C}-$ bending at $1132 \mathrm{~cm}^{-1}$ in the FT-IR spectrum of $\mathrm{NaAlg}^{60}$ was shifted to higher frequencies for stabilized $\mathrm{Cu}$ NPs; this implies that the relative intensity contributions of both overlapped bands are affected by the change in their population because of electrostatic interaction with $\mathrm{Cu}^{0}$.

Bands around $1150-810 \mathrm{~cm}^{-1}$ are representative of pyranose skeleton modes. ${ }^{54,60-62} \mathrm{The}-\mathrm{C}-\mathrm{C}-$ stretching vibrations of mannuronic and gluluronic units are pointed out around $1095 \mathrm{~cm}^{-1} .{ }^{63}$ This band is overlapping with the band corresponding to $-\mathrm{C}-\mathrm{O}-$ stretching, as shown in the secondderivative spectra, with two bands well defined at 1132 and $1095 \mathrm{~cm}^{-1} .{ }^{63}$ When stabilization occurs, both bands appear shifted at higher frequency (around 1147 and $1107 \mathrm{~cm}^{-1}$ ). Jovanović et al ${ }^{51}$ reported that one of the most likely reasons for such shift seems to be the coordination of both $\mathrm{OH}$ and ether groups of NaAlg to silver NPs, which weakened the 

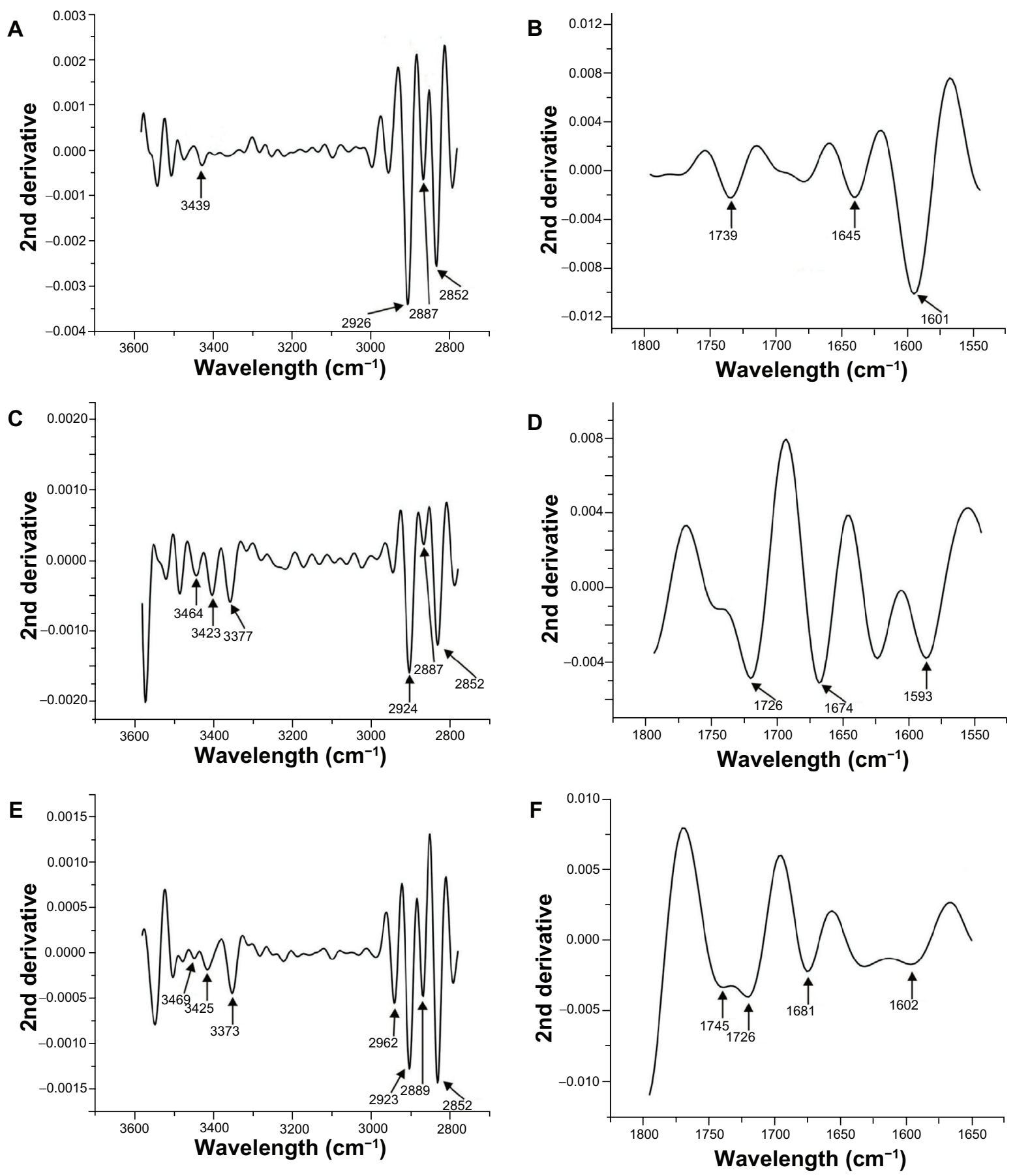

Figure 7 Second-derivative Fourier transform infrared spectroscopy spectra of NaAlg (A and B), Cu-AAI.0-Alg (C and D), and Cu-AA2.5-Alg (E and F).

strength of $\mathrm{CO}$ bond in these two functional groups. The -C $-\mathrm{O}-$ vibrations occurred as a band of high intensity around $1030 \mathrm{~cm}^{-1}$ for the NaAlg, ${ }^{63}$ and stabilized $\mathrm{Cu}$ NPs were observed in the normal mode and second-derivative spectra. For stabilized $\mathrm{Cu}$ NPs, this band overlaps with the bands corresponding to $-\mathrm{C}-\mathrm{C}-$ and $-\mathrm{C}-\mathrm{O}-$ stretching of mannuronic and gluluronic units. No ring opening was suggested by the effect of the increasing of the reducing agent ratio.
Furthermore, in the anomeric or fingerprint region, the IR spectra of polymannuronate and mannopyranuronosyl residues of NaAlg show three bands at 947,893 , and $821 \mathrm{~cm}^{-1}$ in accordance with the second-derivative spectra. These band positions are in agreement with the values reported by Sartori et a $l^{60}$ Chandía et al ${ }^{61}$ and Mathlouthi et al. ${ }^{63}$ These bands are mainly due to the out-of plane deformation of the glycosidic bond on the pyranose rings coupled with other deformation 
vibrations $(\mathrm{C}-\mathrm{H}$ of the $\beta$-mannuronic acid residues and $\mathrm{C}-\mathrm{H}$ of the $\alpha$-gluluronic acid residues)..$^{54,57,64,65}$ For stabilized $\mathrm{Cu}$ NPs, these three bands were shifted to lower frequencies; this implies that the electrostatic interaction with $\mathrm{Cu}^{0}$ may affect the force constants and vibrational amplitudes of the nearest neighbor bonds by steric hindrance, causing the lower strength of the bending vibrations.

\section{D-IR correlation spectra}

The reconstructed data matrix from the three principal components was used instead of the original raw spectral data for the subsequent 2D correlation analysis. PCA factor 1, factor 2 , and factor 3 account for $73.0 \%, 17.4 \%$, and $8.9 \%$, respectively, of the total variance of spectral intensities.

According to the Noda's rule, ${ }^{28}$ strong autopeaks are supposed to appear when any peak in the region of interest changes largely in intensity under a given perturbation. The synchronous plot in the $2000-800 \mathrm{~cm}^{-1}$ region (Figure $8 \mathrm{~A}$ ) shows two strong autopeaks on the diagonal at approximately 1375 and $1035 \mathrm{~cm}^{-1}$ and four weak autopeaks around $1735,1615,1415$, and $1094 \mathrm{~cm}^{-1}$, thus identifying the changes that occur simultaneously in the interaction of $\mathrm{Cu}$ NPs with NaAlg. In order to illustrate the extent of the intensity changes, a power spectrum corresponding to the synchronous correlation intensity along the diagonal line is shown in Figure 9. In this power spectrum, peaks at 1375 and $1035 \mathrm{~cm}^{-1}$ are obviously stronger than peaks at 1735,1615 , 1415 , and $1094 \mathrm{~cm}^{-1}$ (positions identified in the secondderivative spectra). The progress of the interaction between $\mathrm{Cu}^{0}$ and the oxygen of the $-\mathrm{C}=\mathrm{O}$ group also affected the vibrations of the $-\mathrm{C}-\mathrm{O}^{-}$group, the $\mathrm{C}-\mathrm{OH}$ deformation, the $-\mathrm{O}-\mathrm{C}-\mathrm{O}^{-}$symmetric stretching and the $\mathrm{C}-\mathrm{C}$ stretching of

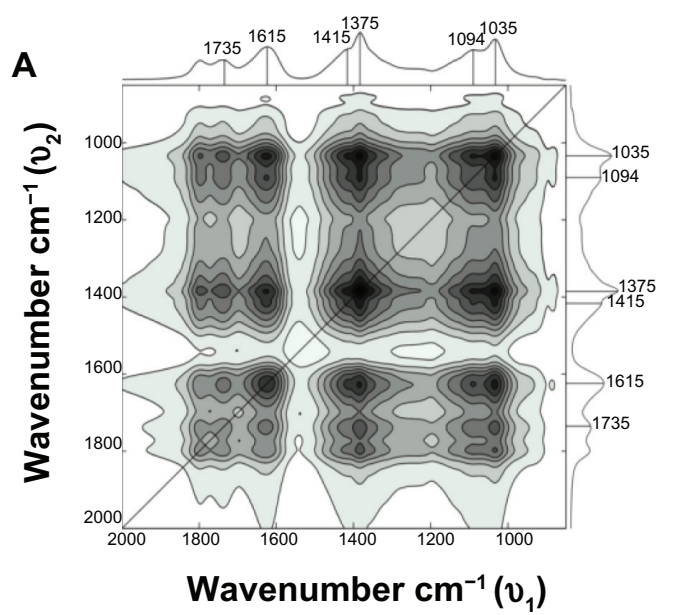

mannuronic and gluluronic units (pyranose rings) due to the high electron density of copper, which produces local bridging attraction depending on the strength and spatial range of $\mathrm{de}-\mathrm{C}-\mathrm{O}-\mathrm{Cu}$ interaction.

The off-diagonal peaks are called cross peaks, and indicate that the two bands change at the same time, though not necessarily in the same direction. A positive synchronous cross peak (solid black area) indicates that the variations in intensity at corresponding frequencies proceed in the same direction during the observation period, while a negative synchronous cross peak shows that the changes are in opposite directions. The synchronous plot shows only positive cross peaks, which means that all peak intensities are changing in the same (positive) direction. This plot is in good agreement with the spectroscopic data shown in Figure 8 and substantiates the fact that in the synchronous plot the interaction of copper to carboxylate ion is apparent as the association of copper to oxygen of hydroxyl groups.

Two broad peaks around 1375 and $1035 \mathrm{~cm}^{-1}$ were observed, which reflect that the symmetric stretching of the carboxylate group $\left(-\mathrm{C}-\mathrm{O}-\mathrm{O}^{-}\right)$varies in the same direction with the $-\mathrm{C}-\mathrm{O}^{-}$group according to the stabilization, as evidenced in the one-dimensional FT-IR spectra. There are two positive cross peaks in respect to a significant autopeak at $1615 \mathrm{~cm}^{-1}\left(1615 / 1375 \mathrm{~cm}^{-1}\right.$ and $\left.1615 / 1035 \mathrm{~cm}^{-1}\right)$, confirming the synchronous changes in the $-\mathrm{C}=\mathrm{O}$ stretching mode of the free $-\mathrm{C}-\mathrm{O}-\mathrm{O}^{-}$and $-\mathrm{C}-\mathrm{O}$ stretching vibrations. Five weak cross peaks to a significant autopeak at $1735 \mathrm{~cm}^{-1}$ were also observed in the synchronous plot $(1735 / 1615,1735 / 1415$, $1735 / 1375,1735 / 1094$, and $1735 / 1035 \mathrm{~cm}^{-1}$ ), indicating that these features are interconnected.

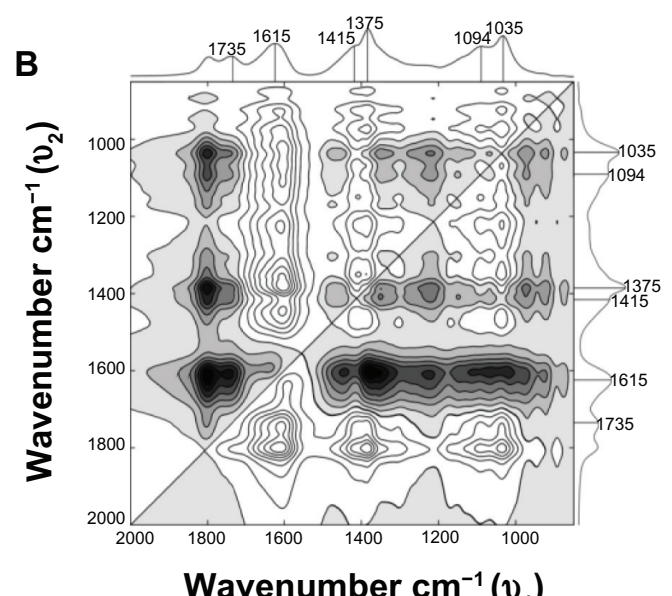

Wavenumber $\mathrm{cm}^{-1}\left(v_{1}\right)$

Figure 8 (A and B) Synchronous and asynchronous two-dimensional correlation spectra in the $2000-800 \mathrm{~cm}^{-1}$ region constructed from the reducing agent-dependent infrared spectra. 


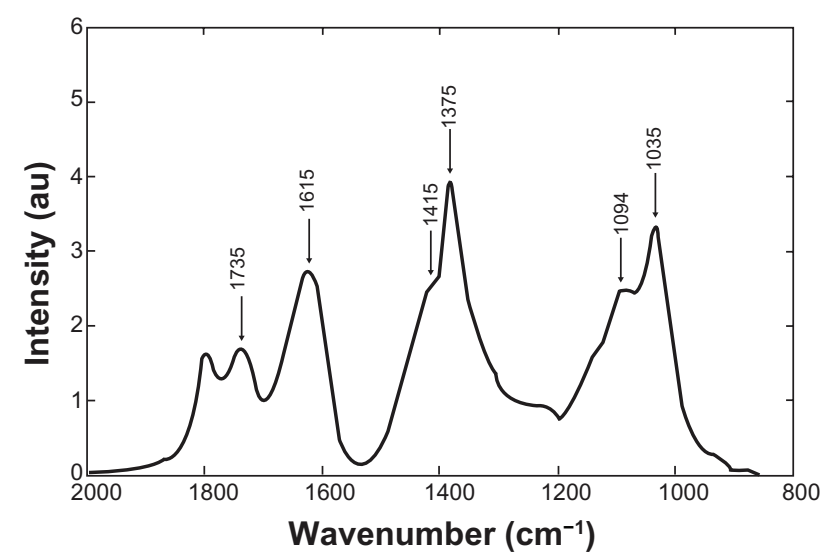

Figure 9 Power spectrum corresponding to the synchronous correlation intensity along the diagonal line in the region of $2000-800 \mathrm{~cm}^{-1}$.

From the corresponding asynchronous plot (Figure 8B), several positive cross peaks can be identified at 1615/1415, $1615 / 1375,1615 / 1094,1615 / 1035,1415 / 1094$, and $1375 / 1094 \mathrm{~cm}^{-1}$. The presence of these cross peaks indeed indicates that the stabilization of $\mathrm{Cu}$ NPs involves sequential events. Negative cross peaks were observed at 1615/1415, $1615 / 1375,1615 / 1094,1615 / 1035$, and 1415/1094 $\mathrm{cm}^{-1}$. Based on Noda's rule ${ }^{28}$ for asynchronous spectra, the spectral intensity change at $1735 \mathrm{~cm}^{-1}$ occurs before 1615,1415 , 1375,1094 , and $1035 \mathrm{~cm}^{-1}$; and $1615 \mathrm{~cm}^{-1}$ occurs after 1415 , 1375,1094 , and $1035 \mathrm{~cm}^{-1}$. Due to the absence of asynchronous peak at 1415/1375, 1415/1035, 1375/1094, 1375/1035, and $1094 / 1035 \mathrm{~cm}^{-1}$ we can only conclude that these pairs of bands vary together. These results suggest that the first event involved in the stabilization is the electrostatic interaction of $\mathrm{Cu}$ NPs with $-\mathrm{C}=\mathrm{O}$, followed by the interaction of copper NPs to the available $\mathrm{O}-\mathrm{C}-\mathrm{O}^{-}$, and finally the association of $\mathrm{Cu}$ NPs to $-\mathrm{OH}$ groups.

\section{Evaluation of antibacterial activity}

The responsibility of biocidal activity of copper and silver species (zerovalent nanoparticles and metal ions released from nanoparticles) has been the subject of considerable debate in recent years. Some studies have reported that the active agent appears to be the ionic species, critical in the electrostatic attraction between negative or positively charged cell membrane of the microorganism. ${ }^{66-68}$ The growth of all tested strains was inhibited by the stabilized $\mathrm{Cu}$ NPs, with both the $\mathrm{MIC}$ and $\mathrm{MBC} \approx 4.0 \mathrm{mg} / \mathrm{L}$ (Table 6); however, $\mathrm{Cu}$ AA2.0-Alg and $\mathrm{Cu}-\mathrm{AA} 2.5-\mathrm{Alg}$ had the highest bactericidal activity. While the growth of most of the tested strains was inhibited by stabilized Cu NPs at $4.0 \mathrm{mg} / \mathrm{L}, S$. enterica serovar Typhimurium had an $\mathrm{MBC}$ of $8.0 \mathrm{mg} / \mathrm{L}$. This is only one tube dilution (twofold) different from $4.0 \mathrm{mg} / \mathrm{L}$. In testing S. aureus ATCC 6538P, the MIC and MBC were $2.0 \mathrm{mg} / \mathrm{L}$ for $\mathrm{Cu}-\mathrm{AA} 2.5-\mathrm{Alg}$. A high percentage of zerovalent $\mathrm{Cu}$ resulted in higher MIC values; however, the extent of decreased activity of Cu-AA1.0-Alg and Cu-AA1.5-Alg was just slightly lower. A decrease in percentage of $\mathrm{Cu}^{0}$ results in approximately a

Table 6 Minimum inhibitory concentration (MIC), minimum bactericidal concentration (MBC), and ratio MBC/MIC of stabilized copper nanoparticles (Cu NPs)

\begin{tabular}{|c|c|c|c|c|c|c|c|c|}
\hline & $\begin{array}{l}\text { Cu-AAI.0 } \\
\text { NPs }\end{array}$ & $\begin{array}{l}\text { Cu-AAI.0- } \\
\text { Alg }\end{array}$ & $\begin{array}{l}\text { Cu-AAI.5 } \\
\text { NPs }\end{array}$ & $\begin{array}{l}\text { Cu-AAI.5- } \\
\text { Alg }\end{array}$ & $\begin{array}{l}\text { Cu-AA2.0 } \\
\text { NPs }\end{array}$ & $\begin{array}{l}\text { Cu-AA2.0- } \\
\text { Alg }\end{array}$ & $\begin{array}{l}\text { Cu-AA2.5 } \\
\text { NPs }\end{array}$ & $\begin{array}{l}\text { Cu-AA2.5- } \\
\text { Alg }\end{array}$ \\
\hline \multicolumn{9}{|c|}{ Staphylococcus aureus ATCC 6538P } \\
\hline MIC & $100 \mathrm{~mL} / \mathrm{L}$ & $4 \mathrm{mg} / \mathrm{L}$ & $100 \mathrm{~mL} / \mathrm{L}$ & $4 \mathrm{mg} / \mathrm{L}$ & $60 \mathrm{~mL} / \mathrm{L}$ & $4 \mathrm{mg} / \mathrm{L}$ & $80 \mathrm{~mL} / \mathrm{L}$ & $2 \mathrm{mg} / \mathrm{L}$ \\
\hline MBC & $100 \mathrm{~mL} / \mathrm{L}$ & $4 \mathrm{mg} / \mathrm{L}$ & $100 \mathrm{~mL} / \mathrm{L}$ & $4 \mathrm{mg} / \mathrm{L}$ & $100 \mathrm{~mL} / \mathrm{L}$ & $4 \mathrm{mg} / \mathrm{L}$ & $100 \mathrm{~mL} / \mathrm{L}$ & $2 \mathrm{mg} / \mathrm{L}$ \\
\hline Ratio MBC/MIC & 1.0 & 1.0 & 1.0 & 1.0 & 1.7 & 1.0 & 1.2 & 1.0 \\
\hline \multicolumn{9}{|c|}{ Salmonella enterica serovar Typhimurium ATCC I33 I I } \\
\hline MIC & $80 \mathrm{~mL} / \mathrm{L}$ & $8 \mathrm{mg} / \mathrm{L}$ & $80 \mathrm{~mL} / \mathrm{L}$ & $8 \mathrm{mg} / \mathrm{L}$ & $80 \mathrm{~mL} / \mathrm{L}$ & $4 \mathrm{mg} / \mathrm{L}$ & $80 \mathrm{~mL} / \mathrm{L}$ & $4 \mathrm{mg} / \mathrm{L}$ \\
\hline MBC & $100 \mathrm{~mL} / \mathrm{L}$ & $8 \mathrm{mg} / \mathrm{L}$ & $100 \mathrm{~mL} / \mathrm{L}$ & $8 \mathrm{mg} / \mathrm{L}$ & $100 \mathrm{~mL} / \mathrm{L}$ & $4 \mathrm{mg} / \mathrm{L}$ & $100 \mathrm{~mL} / \mathrm{L}$ & $8 \mathrm{mg} / \mathrm{L}$ \\
\hline Ratio MBC/MIC & 1.2 & 1.0 & 1.2 & 1.0 & 1.2 & 1.0 & 1.2 & 2.0 \\
\hline \multicolumn{9}{|c|}{ Salmonella enterica serovar Typhimurium ATCC I4028 } \\
\hline $\mathrm{MIC}$ & $80 \mathrm{~mL} / \mathrm{L}$ & $4 \mathrm{mg} / \mathrm{L}$ & $80 \mathrm{~mL} / \mathrm{L}$ & $4 \mathrm{mg} / \mathrm{L}$ & $80 \mathrm{~mL} / \mathrm{L}$ & $2 \mathrm{mg} / \mathrm{L}$ & $80 \mathrm{~mL} / \mathrm{L}$ & $4 \mathrm{mg} / \mathrm{L}$ \\
\hline $\mathrm{MBC}$ & $100 \mathrm{~mL} / \mathrm{L}$ & 4 mg/L & $100 \mathrm{~mL} / \mathrm{L}$ & $4 \mathrm{mg} / \mathrm{L}$ & $100 \mathrm{~mL} / \mathrm{L}$ & $2 \mathrm{mg} / \mathrm{L}$ & $100 \mathrm{~mL} / \mathrm{L}$ & $4 \mathrm{mg} / \mathrm{L}$ \\
\hline Ratio MBC/MIC & 1.2 & 1.0 & 1.2 & 1.0 & 1.2 & 1.0 & 1.2 & 1.0 \\
\hline \multicolumn{9}{|c|}{ Escherichia coli ATCC 25922} \\
\hline $\mathrm{MIC}$ & 80 mL/L & 4 mg/L & $80 \mathrm{~mL} / \mathrm{L}$ & $4 \mathrm{mg} / \mathrm{L}$ & $60 \mathrm{~mL} / \mathrm{L}$ & $4 \mathrm{mg} / \mathrm{L}$ & $80 \mathrm{~mL} / \mathrm{L}$ & $4 \mathrm{mg} / \mathrm{L}$ \\
\hline $\mathrm{MBC}$ & $100 \mathrm{~mL} / \mathrm{L}$ & $4 \mathrm{mg} / \mathrm{L}$ & $100 \mathrm{~mL} / \mathrm{L}$ & $4 \mathrm{mg} / \mathrm{L}$ & $100 \mathrm{~mL} / \mathrm{L}$ & $4 \mathrm{mg} / \mathrm{L}$ & $100 \mathrm{~mL} / \mathrm{L}$ & $4 \mathrm{mg} / \mathrm{L}$ \\
\hline Ratio MBC/MIC & 1.2 & 1.0 & $\mathrm{I} .2$ & 1.0 & 1.7 & 1.0 & 1.2 & 1.0 \\
\hline \multicolumn{9}{|c|}{ Escherichia coli O I57: H7 } \\
\hline $\mathrm{MIC}$ & $80 \mathrm{~mL} / \mathrm{L}$ & $4 \mathrm{mg} / \mathrm{L}$ & $100 \mathrm{~mL} / \mathrm{L}$ & $4 \mathrm{mg} / \mathrm{L}$ & $80 \mathrm{~mL} / \mathrm{L}$ & $4 \mathrm{mg} / \mathrm{L}$ & $100 \mathrm{~mL} / \mathrm{L}$ & $4 \mathrm{mg} / \mathrm{L}$ \\
\hline $\mathrm{MBC}$ & $100 \mathrm{~mL} / \mathrm{L}$ & $4 \mathrm{mg} / \mathrm{L}$ & $100 \mathrm{~mL} / \mathrm{L}$ & $4 \mathrm{mg} / \mathrm{L}$ & $100 \mathrm{~mL} / \mathrm{L}$ & $4 \mathrm{mg} / \mathrm{L}$ & $100 \mathrm{~mL} / \mathrm{L}$ & $4 \mathrm{mg} / \mathrm{L}$ \\
\hline Ratio MBC/MIC & 1.2 & 1.0 & 1.0 & 1.0 & 1.2 & 1.0 & 1.0 & 1.0 \\
\hline
\end{tabular}


Table 7 Antimicrobial activity of the stabilized copper nanoparticles (Cu NPs) in terms of diameter of zone of inhibition

\begin{tabular}{|c|c|c|c|c|c|c|c|}
\hline \multirow[t]{3}{*}{ Microorganism } & \multicolumn{7}{|c|}{ Diameter of zone of inhibition $(\mathrm{mm})^{\mathrm{a}}$} \\
\hline & \multicolumn{4}{|c|}{ Stabilized Cu NPs } & \multicolumn{3}{|c|}{ Standard } \\
\hline & Cu-AAI.0-Alg & Cu-AAI.5-Alg & Cu-AA2.0-Alg & Cu-AA2.5-Alg & Clox & Nitrofuran & Amox \\
\hline Staphylococcus aureus & 10 & 11 & 12 & 11 & 13 & 13 & 36 \\
\hline \multicolumn{8}{|l|}{ ATCC 6538P } \\
\hline Salmonella enterica serovar & 11 & 12 & 10 & 10 & $\mathrm{Nh}$ & $\mathrm{Nh}$ & $\mathrm{Nh}$ \\
\hline \multicolumn{8}{|l|}{ Typhimurium ATCC I33।I } \\
\hline S. enterica serovar Typhimurium & 10 & 10 & 10 & 11 & $\mathrm{Nh}$ & $\mathrm{Nh}$ & $\mathrm{Nh}$ \\
\hline \multicolumn{8}{|l|}{ ATCC 14028} \\
\hline Escherichia coli ATCC 25922 & 9 & 10 & 10 & 10 & $\mathrm{Nh}$ & 12 & $\mathrm{Nh}$ \\
\hline E. coli O I57: $\mathrm{H7}$ & 10 & 11 & 11 & 11 & $\mathrm{Nh}$ & $\mathrm{Nh}$ & 6 \\
\hline
\end{tabular}

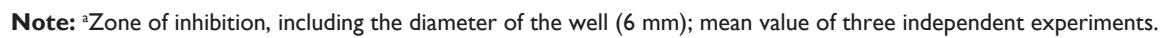

Abbreviations: Nh, no halo; $\mathrm{Nt}$, not tested; Clox, cloxacillin ( $128 \mathrm{mg} / \mathrm{L})$; Amox, amoxicillin (256 mg/mL); Nitrofuran, nitrofurantoin (5/2 mg/mL).

twofold increase. The MBC values were mostly similar to the MIC values of all stabilized $\mathrm{Cu}$ NPs; however, the MBC values of $\mathrm{Cu}-\mathrm{AA} 2.0-\mathrm{Alg}$ and $\mathrm{Cu}-\mathrm{AA} 2.5-\mathrm{Alg}$ varied between 2 and $4 \mathrm{mg} / \mathrm{L}$ for all tested strains. The observed MIC values for stabilized $\mathrm{Cu}$ NPs were comparable to values previously reported by Du et al ${ }^{69}$ for chitosan nanoparticle-loaded copper ions. From these results, it can be understood that the great antibacterial activity of $\mathrm{Cu}-\mathrm{AA} 2.0-\mathrm{Alg}$ and $\mathrm{Cu}-\mathrm{AA} 2.5-\mathrm{Alg}$ is caused by the presence of a large amount of $\mathrm{Cu}^{0}$ in dissolution. The dispersion and further oxidation of zerovalent copper to $\mathrm{Cu}^{2+}$ in liquid cultures could facilitate the continuous release of $\mathrm{Cu}^{2+}$ and ensure the delivery of copper ions in the nutrient media. On the other hand, the agglomeration may affect the outcome and interpretation of antibacterial activity results. This could be the reason for the lower antibacterial activity of Cu-AA1.0-Alg.

Ayala-Núñez et al ${ }^{14}$ define the $\mathrm{MBC} / \mathrm{MIC}$ ratio as "the parameter that reflects the bactericidal capacity of a compound by relating both values. A ratio with a superior value to 1 (MBC $>>$ MIC) indicates that a great amount of compound is needed to reach the bactericidal effect and that this compound could be considered a bacteriostatic agent. Besides, the $\mathrm{MBC} / \mathrm{MIC}$ ratio can reflect if the bacteria are susceptible, tolerant, or resistant to the agent that is being challenged." In accordance with that, the results showed the stabilized Cu NPs inhibited bacterial growth of all strains in a bactericidal rather than a bacteriostatic manner (MBC/ MIC ratio = 1), except for S. enterica serovar Typhimurium ATCC 13311 with Cu-AA2.5-Alg NPs.

Table 7 summarizes the diameters of zone of inhibition of stabilized Cu NPs in millimeters. It is worth pointing out that stabilized $\mathrm{Cu}$ NPs were compared with antibiotics in order to establish a comparison parameter but not to replace antibiotic therapy anytime soon.
Well-diffusion test and dispersed nanoparticles (MIC and $\mathrm{MBC}$ ) showed high variability in results. Stabilized $\mathrm{Cu}$ NPs determined similar zones of inhibition on tested bacteria. The values for diameter of zone of inhibition of the stabilized $\mathrm{Cu}$ NPs vary from 9 to $12 \mathrm{~mm}$ depending on the bacterial strain; however, it was established that stabilized $\mathrm{Cu}$ NPs had antibacterial effects on both Gram-positive and Gram-negative bacteria, showing higher antibacterial activity against E. coli $\mathrm{O} 157$ : H7 and $S$. enterica serovar Typhimurium than some of the standard antibiotics.

Both $E$. coli demonstrated greater sensitivity to stabilized $\mathrm{Cu}$ NPs, which is in accordance with the MIC results. This finding is in agreement with previous studies. ${ }^{3,70}$ As expected, Cu-AA1.0-Alg showed less efficient antibacterial activity against the bacteria studied. It is reasonable to believe that the amount of the $\mathrm{Cu}^{+2}$ ions released from Cu-AA1.0-Alg and $\mathrm{Cu}-\mathrm{AA} 1.5-\mathrm{Alg}$ was inadequate to show antibacterial activity comparable with the other stabilized Cu NPs. Regarding the effects of the antibiotics used as positive controls, only S. aureus registered a higher susceptibility to cloxacillin, in accordance with Turck et al. ${ }^{71}$

\section{Acknowledgments}

This work was supported by FONDECYT 3110094, INNOVA BÍO-BÍO 11-CH S2.1025F11, CONICYT REGIONAL/ CIPA R08C1002 and DIUC 208.036.033-1.0. We gratefully acknowledge the technical assistance of Claudia Rivera, Margarita Torres, and Stefanía Céspedes. Microscopic images were performed in the microscopy laboratory at the University of Concepcion.

\section{Disclosure}

The authors report no conflicts of interest in this work. 


\section{References}

1. Kickelbick G. Hybrid Materials: Synthesis, Characterization and Applications. Weinheim: Wiley-VCH; 2006.

2. Liu J, Aruguete DM, Muruyama M, Hochella MF Jr. Influence of size and aggregation on the reactivity of an environmentally and industrially relevant nanomaterial (PbS). Environ Sci Technol. 2009;43:8178-8183.

3. Ruparelia JP, Chatterjee AK, Duttagupta SP, Mukherji S. Strain specificity in antimicrobial activity of silver and copper nanoparticles. Acta Biomater. 2008;4:707-716.

4. Dang TMD, Le TTT, Fribourg-Blanc E, Dang MC. Synthesis and optical properties of copper nanoparticles prepared by a chemical reduction method. Adv Nat Sci Nanosci Nanotechnol. 2011;2:015009. Epub March 11, 2011.

5. Yu W, Xie H, Chen L, Li Y, Zhang C. Controlled synthesis of narrow-dispersed copper nanoparticles. J Dispers Sci Technol. 2010;31:364-367.

6. Kim YH, Lee DK, Jo BG, Jeong JH, Kang YS. Synthesis of oleate capped $\mathrm{Cu}$ nanoparticles by thermal decomposition. Colloids Surf A Physicochem Eng Asp. 2006;284:364-368.

7. Pham LQ, Sohn JH, Kim CW, et al. Copper nanoparticles incorporated with conducting polymer: effects of copper concentration and surfactants on the stability and conductivity. J Colloid Interface Sci. 2012;365(1):103-109.

8. Holtan S, Bruheim P, Skjak-Braek G. Mode of action and subsite studies of the guluronan block-forming mannuronan C-5 epimerases AlgE1 and AlgE6. Biochemical J. 2006;395:319-329.

9. Liu JW, Zhang Y, Chen D, et al. Facile synthesis of high-magnetization $\gamma$-Fe2O3/alginate/silica microspheres for isolation of plasma DNA. Colloids Surf A Physicochem Eng Asp. 2009;341:33-39.

10. Ozaki Y, Noda I. Two-Dimensional Correlation Spectroscopy: Applications in Vibrational Spectroscopy. New York: John Wiley \& Sons: 2004.

11. Díaz-Visurraga J, Gutiérrez C, von Plessing C, García A. Metal nanostructures as antibacterial agents. In: Méndez-Vilas A, editor. Science And Technology Against Microbial Pathogens: Research, Development and Evaluation. Badajoz: Formatex; 2011:210-218.

12. Wigginton NS, De Titta A, Piccapietra F, et al. Binding of silver nanoparticles to bacterial proteins depends on surface modifications and inhibits enzymatic activity. Environ Sci Technol. 2010;44:2163-2168.

13. Pal S, Tak YK, Song JM. Does the antimicrobial activity of silver nanoparticles depend on the shape of the nanoparticle? A study of the Gram-negative bacterium Escherichia coli. Appl Environ Microbiol. 2007;73:1712-1720.

14. Ayala-Núñez NV, Lara HH, Ixtepan L, Rodríguez C. Silver nanoparticles toxicity and bactericidal effect against methicillinresistant Staphylococcus aureus: nanoscale does matter. Nanobiotechnology. 2009;5:2-9.

15. Diaz-Visurraga J, Garcia A, Cardenas G. Morphological changes induced in bacteria as evaluated by electron microscopy. In: MéndezVilas A, Díaz J, editors. Microscopy: Science, Technology, Applications and Education. Badajoz: Formatex; 2010:307-315.

16. Morones JR, Elechiguerra JL, Camacho A, et al. The bactericidal effect of silver nanoparticles. Nanotechnology. 2005;16(10):2346-2353.

17. Min Y, Akbulut M, Kristiansen K, Golan Y, Israelachvili J. The role of interparticle and external forces in nanoparticle assembly. Nat Mater. 2008;7:527-538.

18. Nel AE, Mädler L, Velegol D, et al. Understanding biophysicochemical interactions at the nano-bio interface. Nat Mater. 2009;8:543-557.

19. Feick JD, Chukwumah N, Noel AE, Velegol D. Altering surface charge nonuniformity on individual colloidal particles. Langmuir. 2004;20:3090-3095.

20. Kim JS, Kuk E, Yu KN, et al. Antimicrobial effects of silver nanoparticles. Nanomedicine. 2007;3:95-101.

21. Panacek A, Kvitek L, Prucek R, et al. Silver colloid nanoparticles: synthesis, characterization, and their antibacterial activity. JPhys Chem B. 2006;110:16248-16253.
22. Yoon K, Byeon JH, Park J, Hwang J. Susceptibility constants of Escherichia coli and Bacillus subtilis to silver and copper nanoparticles. Sci Total Environ. 2007;373:572-575.

23. Blosi M, Albonetti S, Dondi M, Martelli C, Baldi G. Microwaveassisted polyol synthesis of $\mathrm{Cu}$ nanoparticles. J Nanopart Res. 2011;13:127-138.

24. Hall BD, Zanchet D, Ugarte D. Estimating nanoparticle size from diffraction measurements. J Appl Crystallogr. 2000;33:1335-1341.

25. Jung YM, Noda I. New approaches to generalized two-dimensional correlation spectroscopy and its applications. Appl Spectrosc Rev. 2006;41:515-547.

26. Noda I. Generalized two-dimensional correlation method applicable to infrared, Raman, and other types of spectroscopy. Appl Spectrosc. 1993;47:1329-1336.

27. Peterson LR, Shanholtzer CJ. Tests for bactericidal effects of antimicrobial agents: technical performance and clinical relevance. Clin Microbiol Rev. 1992;5:420-432.

28. Vossmeyer T, Katsikas L, Giersig M, Popovic IG, Diesner K, Chemseddine A. CdS Nanoclusters: synthesis, characterization, size dependent oscillator strength, temperature shift of the excitonic transition energy, and reversible absorbance shift. J Phys Chem. 1994;98:7665-7673.

29. Joint Committee on Powder Diffraction Standards, File 85-1326; 1999.

30. Joint Committee on Powder Diffraction Standards, File 77-0199; 1997.

31. Mayoral MC, Andrés JM, Bona MT, Higuera V, Belzunce FJ. Yttria stabilized zirconia corrosion destabilization followed by Raman mapping. Surf Coat Technol. 2008;202(21):5210-5216.

32. West A. Solid State Chemistry and Its Applications. Chichester: Wiley; 1984.

33. Cohen JB. X-ray diffraction studies of catalysts. Ultramicroscopy. 1990;34(1-2):41-46.

34. Calvin S, Luo SX, Caragianis-Broadbridge C, et al. Comparison of extended $\mathrm{x}$-ray absorption fine structure and Scherrer analysis of $\mathrm{X}$-ray diffraction as methods for determining mean sizes of polydisperse nanoparticles. Appl Phys Lett. 2005;87(23):233102. Epub November 28, 2005.

35. Chiche D, Digne M, Revel R, Chanéac C, Jolivet JP. Accurate determination of oxide nanoparticle size and shape based on $\mathrm{X}$-ray powder pattern simulation: application to boehmite $\mathrm{AlOOH}$. J Phys Chem C. 2008;112(23):8524-8533.

36. Zhu HT, Zhang CY, Yin YS. Rapid synthesis of copper nanoparticles by sodium hypophosphite reduction in ethylene glycol under microwave irradiation. J Cryst Growth. 2004;270(3-4):722-728.

37. Bönnemann H, Richards RM. Nanoscopic metal particles - synthetic methods and potential applications. Eur J Inorg Chem. 2001;10: 2455-2480.

38. Patakfalvi R, Papp S, Dekany I. The kinetics of homogeneous nucleation of silver nanoparticles stabilized by polymers. J Nanopart Res. 2007;9:353-364.

39. Ghodselahi T, Vesaghi MA, Shafiekhani A. Study of surface plasmon resonance of $\mathrm{Cu} @ \mathrm{Cu} 2 \mathrm{O}$ core-shell nanoparticles by Mie theory. J Phys D Appl Phys. 2009;42:015308. Epub December 15, 2008 .

40. Kanninen P, Johans C, Kyosti Kontturi JM. Influence of ligand structure on the stability and oxidation of copper nanoparticles. J Colloid Interface Sci. 2008;318(1):88-95.

41. Dung TM, Tuyet TT, Fribourg-Blanc E, Chien M. The influence of solvents and surfactants on the preparation of copper nanoparticles by a chemical reduction method. Adv Nat Sci Nanosci Nanotechnol. 2011;2:025004. Epub April 21, 2011.

42. Brege JJ, Hamilton CE, Crouse CA, Barron AR. Ultrasmall copper nanoparticles from a hydrophobically immobilized surfactant template. Nano Lett. 2009;9(6):2239-2242.

43. Feng G, Qiang W, Zhu HT, Xun F, Hu ZS. Preparation of stable colloids of copper nanoparticles in organic solvent with amphiphilic polymer. Rare Metal Mat Eng. 2003;32(1):733-735. 
44. Mehta VP, Khanna RK, Talesara PR, Sharma R. Dielectric-relaxation studies of the system copper (II) soap nonpolar solvent at microwavefrequencies. Asian J Chem. 1995;7(3):648-650.

45. Luechinger NA, Athanassiou EK, Stark WJ. Graphene-stabilized copper nanoparticles as an air-stable substitute for silver and gold in low-cost ink-jet printable electronics. Nanotechnology. 2008;19(44):445201. Epub September 26, 2008.

46. Wang S, Huang X, HeY, et al. Synthesis, growth mechanism and thermal stability of copper nanoparticles encapsulated by multi-layer graphene. Carbon. 2012;50:2119-2125.

47. Pathak TS, Kim JS, Lee S-J, Baek D-J, Paeng K-J. Preparation of alginic acid and metal alginate from algae and their comparative study. J Polym Environ. 2008;16:198-204.

48. Zohuriaan MJ, Shokrolahi F. Thermal studies on natural and modified gums. Polym Test. 2004;23(5):575-579.

49. Cárdenas G, Díaz J, García A, Meléndrez MF, Cruzat C. Colloidal Cu nanoparticles/chitosan composite film obtained by microwave heating for food package applications. Polym Bull. 2009;62:511-524.

50. Soares JP, Santos JE, Chierice GO, Cavalheiro ETG. Thermal behavior of alginic acid and its sodium salt. Ecl Quím. 2004;29(2):57-63.

51. Jovanović Ž, Stojkovska J, Obradović B, Mišković-Stanković V. Alginate hydrogel microbeads incorporated with Ag nanoparticles obtained by electrochemical method. Mater Chem Phys. 2012;133(1):182-189.

52. Leal D, Matsuhiro B, Rossib M, Caruso F. FT-IR spectra of alginic acid block fractions in three species of brown seaweeds. Carbohydr Res. 2008;343:308-316.

53. Habibi MH, Hassanzadeh A, Zeini-Isfahani A. Spectroscopic studies of Solophenyl red 3BL polyazo dye tautomerism in different solvents using UV-visible, 1H NMR and steady-state fluorescence techniques. Dyes Pigm. 2006;69(1-2):93-101.

54. Popescu CM, Popescu MC, Singurel G, Vasile C, Argyropoulos DS, Willfor S. Spectral characterization of eucalyptus wood. Appl Spectrosc. 2007;61:1168-1177.

55. Chen JP, Hong L, Wu S, Wang L. Elucidation of interactions between metal ions and ca alginate-based ion-exchange resin by spectroscopic analysis and modeling simulation. Langmuir. 2002;18(24):9413-9421.

56. Valentin R, Horga R, Bonelli B, Garrone E, Di Renzo F, Quignard F. FTIR Spectroscopy of $\mathrm{NH}_{3}$ on acidic and ionotropic alginate aerogels. Biomacromolecules. 2006;7(3):877-882.

57. Sekkal M, Dincq V, Legrand P, Huvenne JP. Investigation of the glycosidic linkages in several oligosaccharides using FT-IR and FT Raman. J Mol Struct. 1995;349:349-352.
58. Lim SF, Zheng YM, Zou, SW, Chen, JP. Characterization of copper adsorption onto an alginate encapsulated magnetic sorbent by a combined FT-IR, XPS and mathematical modeling study. Environ Sci Technol. 2008;42(7):2551-2556.

59. Nivens D, Ohman DE, Williams J, Franklin MJ. Role of alginate and its $\mathrm{O}$ acetylation in formation of Pseudomonas aeruginosa microcolonies and biofilms. J Bacteriol. 2001;183(3):1047-1057.

60. Sartori C, Finch DS, Ralph B. Determination of the cation content of alginate thin films by FT IR spectroscopy. Polymer. 1997;38(1):43-51.

61. Chandía NP, Matsuhiro B, Mejías E, Moenne A. Alginic acids in Lessonia vadosa: partial hydrolysis and elicitor properties of the polymannuronic acid fraction. J Appl Phycol. 2004;16(2):127-133.

62. Salomonsen T, Jensen HM, Stenbak D, Engelsen SB. Chemometric prediction of alginate monomer composition: a comparative spectroscopic study using IR, Raman, NIR and NMR. Carbohydr Polym. 2008;72(4):730-739.

63. Mathlouthi M, Koenig JL. Vibrational spectra of carbohydrates. In: Tipson RS, Derek H, editors. Advances in Carbohydrate Chemistry and Biochemistry. Waltham: Academic Press; 1987:7-89.

64. Fuks L, Filipiuk D, Lewandowski W. Lanthanide ions complexation by uronic acids. J Mol Struct. 2001;563-564:587-593.

65. Filipiuk D, Fuks L, Majdan M. Transition metal complexes with uronic acids. J Mol Struct. 2005;744-747:705-709.

66. Hamouda T, Myc A, Donovan B, Shih A, Reuter JD, Baker JR. A novel surfactant nanoemulsion with a unique non-irritant topical antimicrobial activity against bacteria, enveloped viruses and fungi. Microbiol Res. 2000;156:1-7.

67. Dibrov P, Dzioba J, Gosink KK, Hase CC. Chemiosmotic mechanism of antimicrobial activity of Ag+ in Vibrio cholerae. Antimicrob Agents Chemother. 2002;46:2668-2670.

68. Dragieva I, Stoeva S, Stoimenov P, Pavlikianov E, Klabunde K. Complex formation in solutions for chemical synthesis of nanoscaled particles prepared by borohydride reduction process. Nanostruct Mater. 1999;12:267-270

69. Du W, Xu Y, Xu Z, Fan C. Preparation, characterization and antibacterial properties against $E$. coli $\mathrm{K} 88$ of chitosan nanoparticle loaded copper ions. Nanotechnology. 2008;19(8):085707. Epub February 4, 2008.

70. Qi L, Xu Z, Jiang X, Hu C, Zou X. Preparation and antibacterial activity of chitosan nanoparticles. Carbohydr Res. 2004;339(16):2693-2700.

71. Turck M, Ronald A, Petersdorf RG. Clinical studies with cloxacillin. JAMA. 1965;192(11):961-963.
International Journal of Nanomedicine

\section{Publish your work in this journal}

The International Journal of Nanomedicine is an international, peerreviewed journal focusing on the application of nanotechnology in diagnostics, therapeutics, and drug delivery systems throughout the biomedical field. This journal is indexed on PubMed Central, MedLine, CAS, SciSearch ${ }^{\circledR}$, Current Contents ${ }^{\circledR} /$ Clinical Medicine,

\section{Dovepress}

Journal Citation Reports/Science Edition, EMBase, Scopus and the Elsevier Bibliographic databases. The manuscript management system is completely online and includes a very quick and fair peer-review system, which is all easy to use. Visit http://www.dovepress.com/ testimonials.php to read real quotes from published authors. 